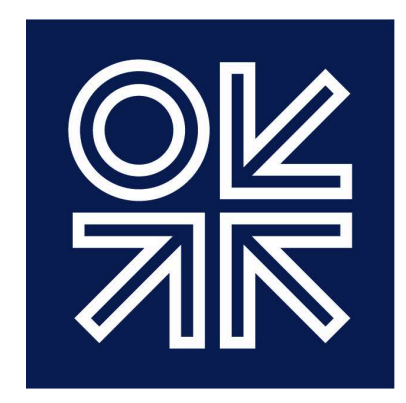

THE OXFORD INSTITUTE FOR ENERGY STUDIES

MAY 2014

\title{
Divergent Paths to a Common Goal?
}

An Overview of Challenges to Electricity Sector Reform in Developing versus Developed Countries

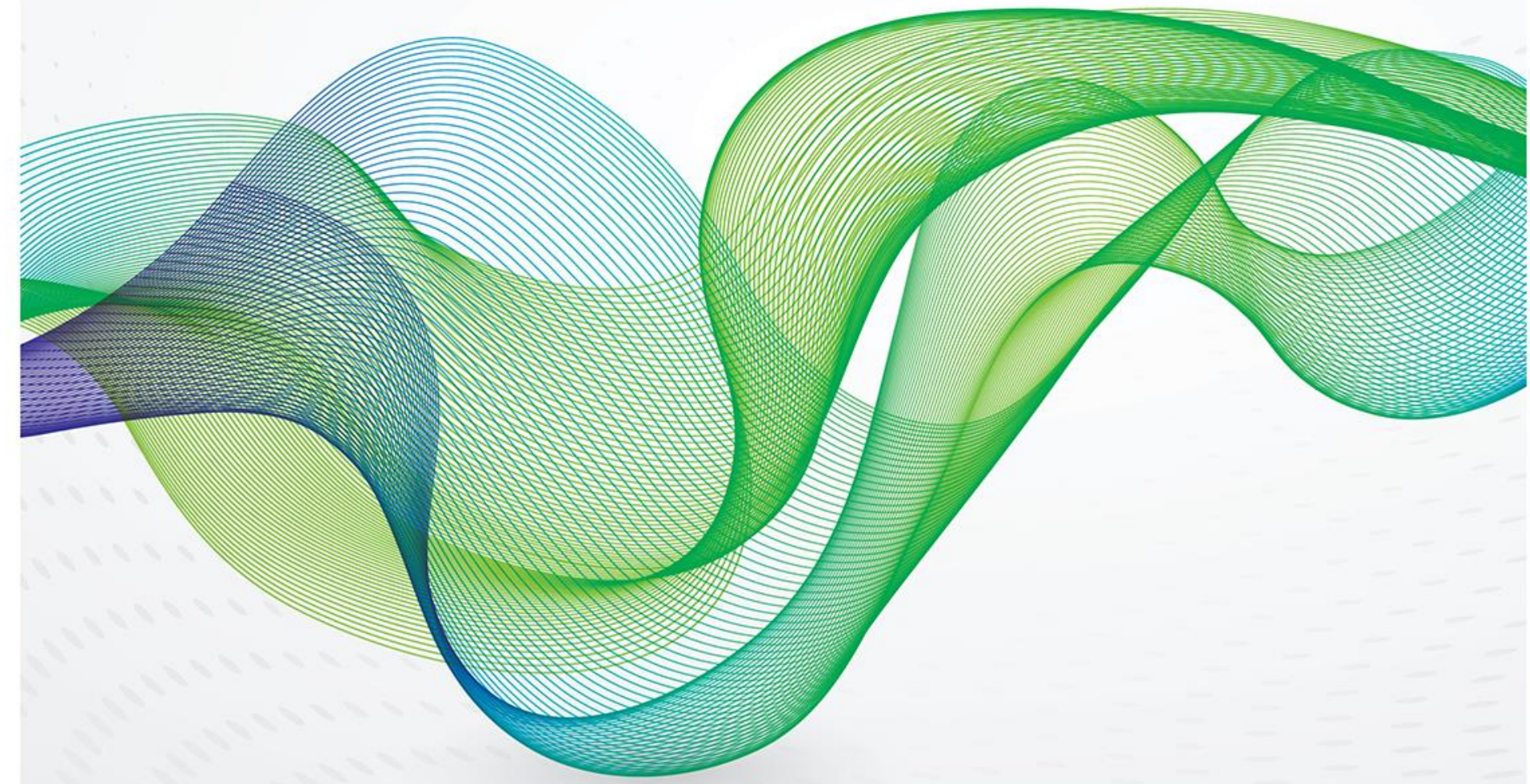

Anupama Sen* 

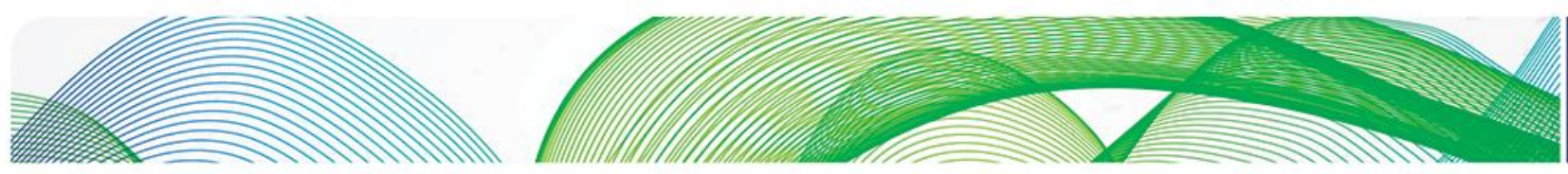

\section{O는}

The contents of this paper are the author's sole responsibility. They do not necessarily represent the views of the Oxford Institute for Energy Studies or any of its members.

Copyright (C) 2014

Oxford Institute for Energy Studies

(Registered Charity, No. 286084)

This publication may be reproduced in part for educational or non-profit purposes without special permission from the copyright holder, provided acknowledgment of the source is made. No use of this publication may be made for resale or for any other commercial purpose whatsoever without prior permission in writing from the Oxford Institute for Energy Studies.

ISBN 978-1-78467-002-3 

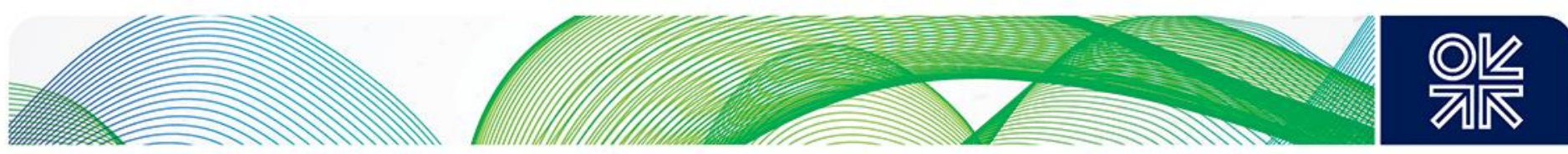

\begin{abstract}
Recent experiences in electricity market reform have reignited an enduring debate in economics and public policy, namely, the benefits of liberalized markets versus central planning in the provision of goods and services. This debate as it relates to energy is not new - there has been previous criticism of whether liberalized markets in the energy sector have delivered optimal outcomes on objectives related to pricing, investment, storage, and overall 'security of supply'. However, the debate has arguably taken on new and greater relevance for two reasons. The first relates to the role of the electricity sector in decarbonization, and the argument that the sector provides the most direct and substantial way of reducing greenhouse gas emissions given the growing urgency of the environmental impacts of non-action. The second has wider ranging, global implications, given that many developing countries - which stand to lose the most from the environmental impacts of climate change - have been progressively moving towards electricity market liberalization since the 1990s, after having adopted variations of this model following its relatively successful reception in the developed world at the time. What then are the implications of the fact that developed and developing countries could end up moving in opposite policy directions - the former towards central planning and the latter towards markets - in the pursuit of a shared eventual goal, that is, climate change mitigation through the proliferation of renewable energy in the electricity sector? This paper summarizes this debate and sketches out areas of policy relevance as they pertain to developing countries.
\end{abstract}



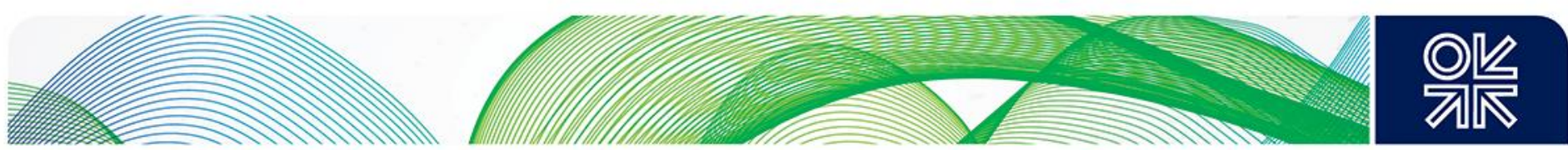

\section{Acknowledgements}

The author is extremely grateful to Malcolm Keay, John Rhys, David Robinson, Christopher Allsopp and Bassam Fattouh for their time and patience in reviewing drafts of this paper. Many thanks to Kate and Catherine for their help in preparing it for publication.

May 2014 

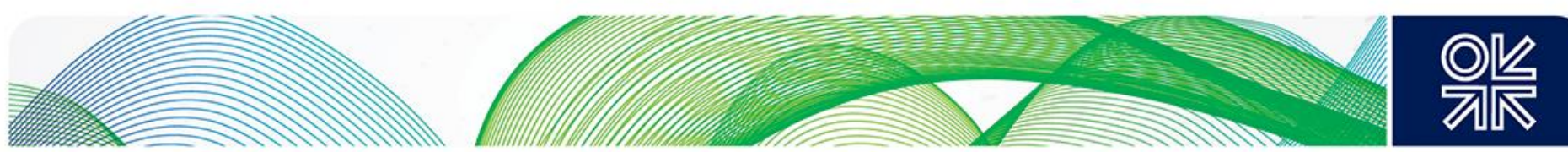

\section{Contents}

Abstract iii

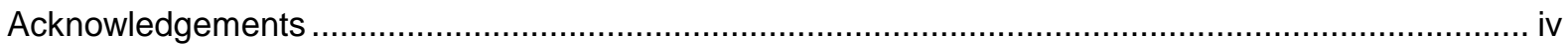

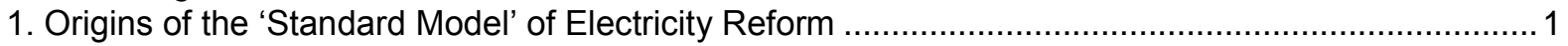

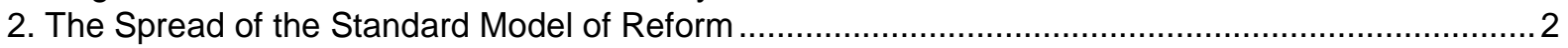

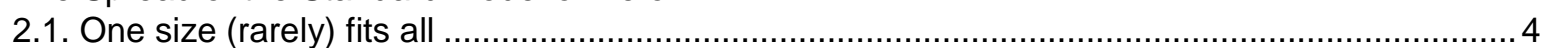

3. The Problem with the Standard Model: Economics versus Policy ........................................... 7

3.1. Price setting in the standard model and the issues of incorporating renewables .................... 7

3.2 The effects of emissions reduction targets on the standard model ...................................... 9

4. The Implications for Electricity Reform in Developing Countries .......................................... 10

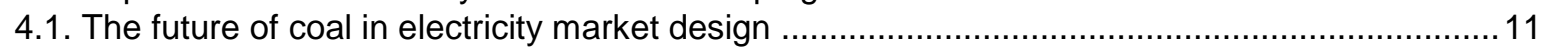

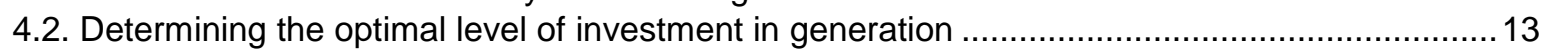

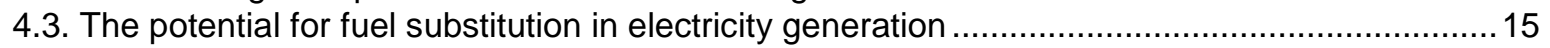

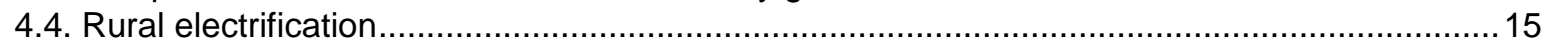

4.5. Infrastructure and smart grids - identifying the prerequisites ........................................... 16

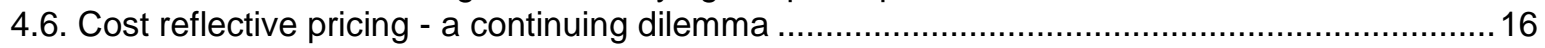

4.7. Regional electricity market integration - opportunities and implications .............................17

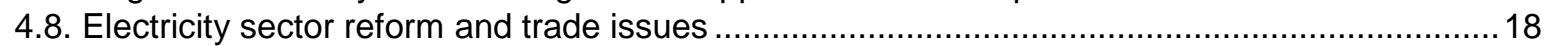

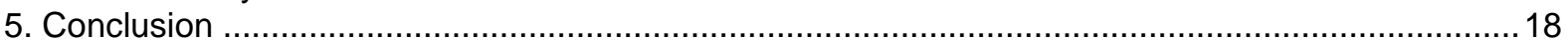

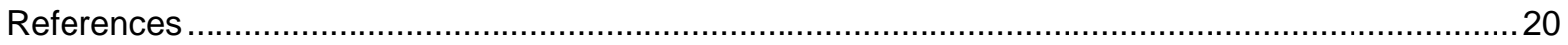

Appendix A: Estimated Levelized Cost of New Generation Resources, 2018 (2011US\$/Megawatt

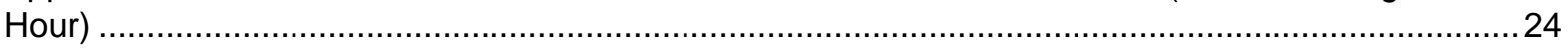

\section{Figures}

Figure 2.1: Average Tariffs below Average Costs in the Indian Electricity Sector............................ 3

Figure 2.2: The Standard Model as Applied to India .............................................................. 6

Figure 4.1 Percentage Shares of Fuel Sources in Electricity Generation, 2035 .............................. 12

\section{Tables}

Table 2.1: Structure of the Electricity Sector in Developing Countries .......................................... 5

Table 4.1: Per Capita Emissions by Sector, 2010 (kg of $\mathrm{CO}_{2}$ per capita) ...................................11 

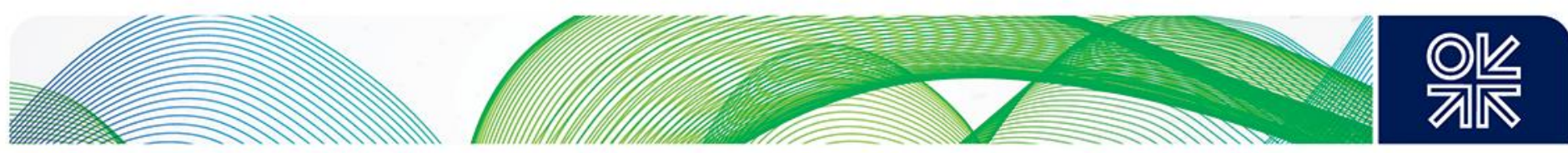

\section{Origins of the 'Standard Model' of Electricity Reform}

Electricity reform programmes originated in the experiences of a group of countries in the 1980s and 1990s. These were primarily the United Kingdom (England and Wales) which is largely considered a pioneer in electricity market liberalization in the OECD, as well as Norway, the USA, and Chile whose relatively early reform experience (beginning in the 1980s) is often highlighted as a forerunner to reforms in other economies (Pollitt, 2004). Essentially, reform entailed restructuring the sector from a scenario characterised by state-owned, vertically integrated entities, into one where smaller, and in most cases privately-owned firms, competed against each other in the business of electricity provision. From these countries' experiences emerged a raft of basic reform measures or 'blueprint', which included:

$$
\begin{aligned}
& \text { - the opening up of the electricity sector to Independent Power Producers (IPPs) }{ }^{1} \\
& \text { - the corporatization }{ }^{2} \text { of vertically integrated state-owned utilities and the commercialization } \\
& \text { of their functions, } \\
& \text { - the enactment of electricity legislation, } \\
& \text { - the establishment of an independent electricity regulator, } \\
& \text { the unbundling of vertically integrated utilities into competitive (generation and retail } \\
& \text { supply) and non-competitive (transmission and distribution network) segments, and } \\
& \text { the divestiture or privatization of the competitive segments of the electricity sector. }
\end{aligned}
$$

Collectively, these measures came, over time, to be known as the 'standard model' of electricity reform. ${ }^{3}$ Wholesale markets featured prominently in the details of the standard model, as did retail competition and consumer choice.

Although the arguments in favour of electricity market reform via the standard model have primarily focused on its economic benefits, ${ }^{4}$ the literature presents mixed evidence on whether the predominant drivers behind initial reform, particularly in the UK, were purely economic, or ideological (Newbery, 2013; Rutledge, 2010; Helm, 2010; Keay, 2009). It has even been suggested that the economic rationale for electricity market liberalization evolved ex post and was secondary to ideological and political considerations (Rutledge, 2010).

While the implicit goal of the standard model was complete liberalization, together with the establishment of wholesale markets and competition in generation and retail supply, along with the privatization of state-owned entities, it must be noted that privatization was not necessarily seen as requisite to the success of electricity sector reform. Norway, for instance, is widely considered to have successfully restructured its electricity provision within the public sector, creating a number of

\footnotetext{
${ }^{1}$ Privately owned electricity generation companies which produce electricity for sale to utilities.

2 The creation of separate legal entities.

${ }^{3}$ This has also been referred to as the 'textbook' model or the 'prescriptive' approach (Gratwick and Eberhard, 2008; Joskow, 2008; Victor and Heller, 2007).

${ }^{4}$ These economic benefits specifically pertain to improvements in the efficiency of operation of utilities brought about by greater competition, which could then be passed on to consumers through competitive (potentially lower) prices and better quality of service.
}

May 2014: Divergent Paths to a Common Goal? An Overview of Challenges to Electricity Sector Reform in Developing versus Developed Countries 

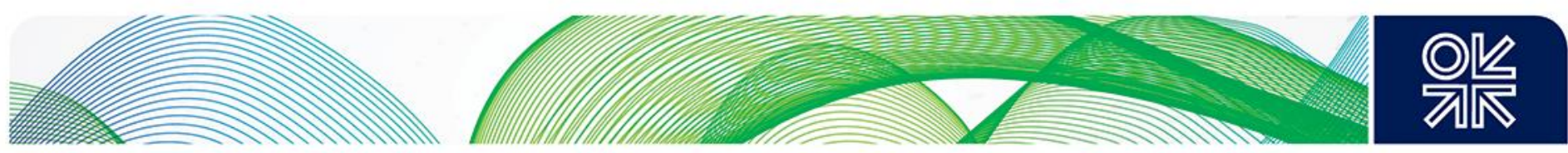

competing state-owned utilities and structures. Electricity sector reforms in developed economies are largely deemed to have been successful, although some of the literature suggests that it is difficult to attribute the improvements in operational efficiency to reform per se when there has been a combination of external factors. ${ }^{5}$ There is a vast amount of literature documenting the early experience of electricity sector reform in developed countries. ${ }^{6}$

\section{The Spread of the Standard Model of Reform}

From the 1990s onwards, there was a gradual and widespread adoption of the standard model of electricity reform across the developing world. The drivers behind this have been categorized into 'pull factors' and 'push factors' (Zhang et al., 2008; Nepal and Jamasb 2011). The 'pull' factors included a demonstration effect following experiences in the UK, Norway, and Chile (Zhang et al., 2008).

The 'push factors' were twofold; the first was related to the adoption of structural adjustment programmes by developing economies, such as India, in cooperation with multilateral lending agencies, such as the World Bank and the IMF, as a condition of multilateral financial assistance following balance of payments crises. ${ }^{7}$ The second 'push factor' was related to endemic problems within the electricity sectors of developing countries, and a genuine need for reform. The electricity sector in most developing countries was owned and operated within the public domain, through vertically integrated entities which carried out the functions of generation, transmission, and distribution, as well as infrastructure creation. Vertically integrated regional or national monopolies, based on the economies of scale and scope $^{8}$ argument, were initially deemed to be the best way of extending electricity to the overwhelming majority of the poor populations of developing countries that lacked access to it. Similarly, public ownership was justified on the basis that the state was the custodian of public interest, the enabler of necessary coordination among different segments (generation, transmission, and distribution), and was necessary to the strategic nature of the sector, given its role in economic development (Gratwick and Eberhard, 2008). This led to the state holding a monopoly over the sector in countries such as India - with State Electricity Boards operating under state governments - and China - with provincial power bureaus operating under the Ministry of Electrical Power (Andrews-Speed, 2013).

The concentration of all functions in singular state-owned entities, with what amounted to no effective self-imposed or independent oversight, led to technical and financial problems, and there is substantial literature documenting this for various countries (Victor and Heller 2007; Tongia, 2007). For instance, transmission and distribution losses in developing economies averaged 20 per cent prior to reform, in comparison with a world average of 9 per cent (Gratwick and Eberhard, 2008). There were also operational inefficiencies; one efficiency indicator - the number of employees per

\footnotetext{
${ }^{5}$ For example, falling prices of fuel inputs could have coincided with reform; similarly, improved labour productivity could simply be attributed to cuts in the labour force following privatization (Rutledge, 2010). The existence of excess capacity at the outset in most of these early reformer countries was also indicative of lower risks in carrying out reforms.

${ }^{6}$ Some key references are Newbery (2013); Keay et al. (2013a; 2013b); Rutledge (2010); Bye and Hope (2005); Magnus (1997); Newbery and Pollitt (1997).

The literature indicates that much of this was tied to the introduction of private investment through IPPs (Williams and Ghanadan, 2006).

8 That is, limiting the risks associated with large-scale investment. Governments can also use a public or privately owned monopoly to finance public objectives that the company may otherwise not undertake, such as rural electrification.
} 

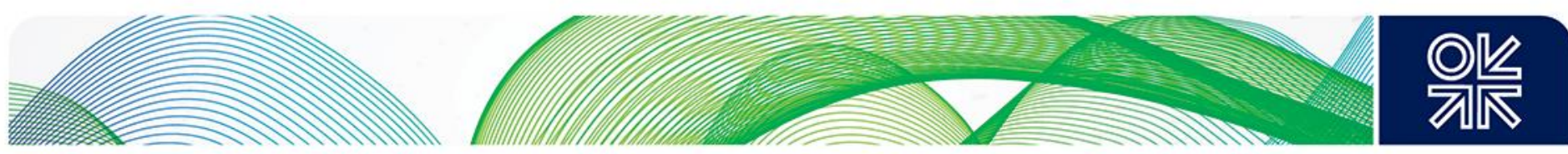

million units of electricity sold - was 5 for India, compared with 0.1 for Norway ${ }^{9}$ (Sen and Jamasb, 2013; Gol, 2011). ${ }^{10}$ There is an abundance of literature attributing the underlying reasons for these technical and financial inefficiencies in developing economies, such as India, to the politicization of the electricity sector and its capture and use by politicians to seek votes through the promise of free or low-priced electricity, partly financed through subsidies on government budgets, ${ }^{11}$ and partly by the state-owned enterprises themselves. Such actions forced state-owned enterprises to keep prices below costs of supply, constraining the amount by which prices could be adjusted upwards against increases in the cost of supply (see Figure 2.1). This in turn limited the amount of capital available for reinvestment in infrastructure creation and for the expansion of electricity access - thereby defeating the original purpose of state-controlled electricity provision and engendering a culture of wastefulness and political opportunism (Tongia, 2007; Dubash and Singh, 2005). In India, this circular problem was demonstrated by the fact that, despite successive increases in the amount of expenditure allocated to electricity within the Five Year Plans, capacity addition targets were rarely achieved and state-owned utilities continued to accumulate massive losses. ${ }^{12}$

Figure 2.1: Average Tariffs below Average Costs in the Indian Electricity Sector

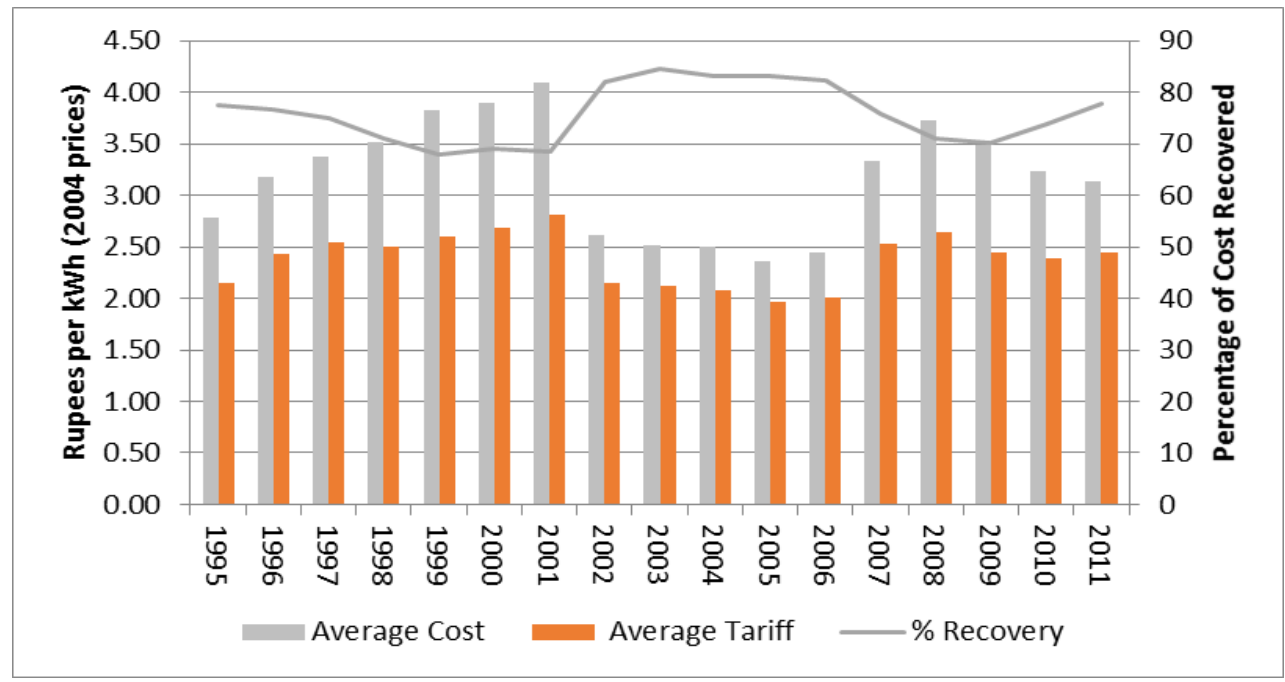

Source: Sen and Jamasb (2013); Gol (2011).

The 'push' factors behind the adoption of reform were, therefore, arguably different in developing and developed countries. In developed (OECD) countries, the underlying logic and objectives for reform (although, as some argue, ex post), were higher efficiency, lower prices, consumer choice, and national competitiveness (Williams and Ghanadan, 2006). ${ }^{13}$ In developing (non-OECD) countries, the objectives of reform were more to do with the declining state of utilities' finances, the propagation of greater private investment in order to enable the servicing of debt and the expansion of investment in

\footnotetext{
${ }^{9}$ Norway, as mentioned earlier, carried out reforms entirely within the public sector.

${ }^{10}$ However, in developing countries, there was a difference between technical losses and theft, which signified the social and poverty issues that these countries faced.

${ }^{11}$ Which formed a part of the fiscal deficit.

12 The biggest underachievement was arguably in India's recent $11^{\text {th }}$ Five Year Plan (2002-7), where only 56\% of planned capacity addition targets were achieved (Sen and Jamasb, 2013).

${ }^{13}$ Although the political factors underpinning electricity reform in the UK included weakening the power of the coal unions and the CEGB, there was also the expectation that competition would lead to improvements in the efficiency of operations. Further, privatization and restructuring in a system with excess supply involved very little risk. It has in fact been argued that governments will tend to liberalize when system Average Costs are above system Marginal Costs, and vice versa (Kahn, 1979).
}

May 2014: Divergent Paths to a Common Goal? An Overview of Challenges to Electricity Sector Reform in 

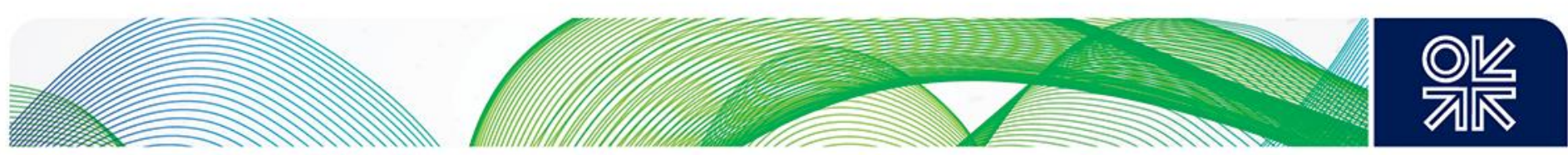

infrastructure and technology upgrades, and the removal of the electricity supply constraint on growth. (Williams and Ghanadan, 2006). Developing economies also faced a capacity shortage, which meant that the risks in reform were higher at the outset in comparison with developed economies.

At the time of initial reform, the standard model, with its focus on efficiency improvements through unbundling, corporatization, and competition, was presented as a solution aimed at addressing these technical and financial inefficiencies and at infusing transparency into the operations of state-owned enterprises in developing economies. Further, it potentially enabled the separation of the economics of electricity provision from politics. ${ }^{14}$ Technological advancements had also rendered the economies of scale argument redundant. Thus, the standard model effectively represented a 'common path' but to 'different goals' for developed and developing economies. Whilst some developing economies proactively adopted the standard model, or elements of it (such as China), others in a sense had it imposed upon them (such as India, following a balance of payments crisis in 1991). Further, although there was a general sequence that had been intended to shape the basic reform measures, ${ }^{15}$ developing economies ended up adopting variations of it, as reform tended to occur in fits and starts rather than follow a smooth sequential process.

\subsection{One size (rarely) fits all}

Despite debates over whether the standard model continued to be uniformly imposed upon developing economies as part of a wider agenda, ${ }^{16}$ the literature indicates that in fact it quickly became apparent that a 'one-size-fits-all' approach did not work; one of the factors in this was the realization that developing economies often lacked the strong institutions required to underpin successful reform (Gratwick and Eberhard, 2008). In subsequent assessments, such factors as the strength of institutions, the extent of initial resource endowments, and the size of electricity systems were all identified as having the potential to affect outcomes (Jamasb et al. 2004; Nepal and Jamasb, 2011). Differences in starting conditions were also important. For instance, reforms were adopted in China in the late 1990s when there was a surplus of generating capacity - this was similar to the situation of excess capacity that existed in developed economies (Andrews-Speed, 2013) - whereas in India they were adopted in the early 1990s during a period of power shortages. The concept of 'reregulation' was highlighted in response to this, focusing on the creation of regulatory institutions to ensure that utilities, whether publicly or privately owned, had sufficient oversight and autonomy to improve performance before reform progressed to liberalized markets (Gratwick and Eberhard, 2008). ${ }^{17}$

Two factors have stood out in the vast literature on why developing economies have been unsuccessful in implementing reforms through to a complete version of the standard model, or a close variation of it. The first is the continual inability of governments to implement cost-reflective pricing. This has given rise to a circular problem: the absence of cost-reflective pricing to begin with implied that initial reform was likely to lead to a period of rising prices; thus public opposition to these price increases typically created an ex ante impediment to the complete adoption of reform (Sen and Jamasb, 2013; Littlechild, 2000; Newbery, 2000). ${ }^{18}$ Related to this factor is the sequencing of reform

\footnotetext{
${ }^{14}$ Although, as discussed later, the politics eventually re-adapted (Dubash, 2011).

${ }^{15}$ A 'scorecard' for electricity reforms, citing the different steps and the sequence, was developed to broadly measure progress (Bacon, 1999).

${ }^{16}$ That is, as a condition of lending by multilateral finance institutions, such as the World Bank and IMF.

17 The literature indicates that this first proposed in a discussion paper as early as 1990 (Gratwick and Eberhard, 2008).

${ }^{18}$ It can also be reiterated here that the absence of excess capacity to begin with in many developing countries also created an ex ante impediment to reform.
} 

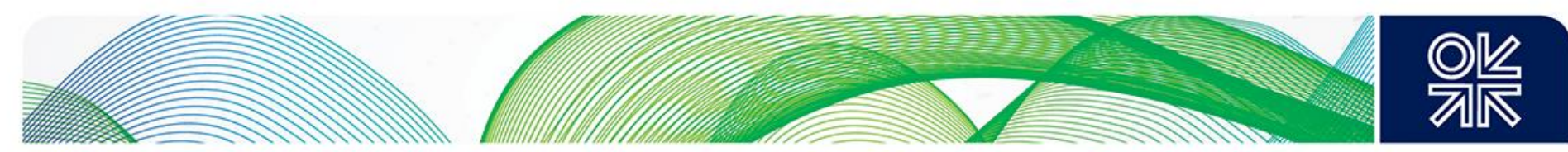

measures as an impediment to successful outcomes, and the issue of whether reforms were carried out 'too far, too fast'. For instance, in the Indian state of Orissa, distribution utilities were privatized in the 1990s without adequate restructuring or commercialization, which resulted in the creation of private sector liabilities in the place of public ones.

A second factor is a shift, in the 2000s, in the focus of reforms from improvements in the financial and operating efficiency of utilities, to capacity addition and the ramping up of power generation, given growing concerns over 'energy security', ${ }^{19}$ shortages, and blackouts. This was the case, for instance, in India, China, and Brazil (Sen and Jamasb, 2013; Andrews-Speed, 2013; Rosa et al., 2013). In India, captive generation 20 for industry was particularly encouraged as a way of circumventing problems with the lack of capacity addition on the grid; ${ }^{21}$ it has in fact been argued that this 'dichotomy' in electricity sector structure - where the state sector exists alongside the private sector has an underlying political basis (Joseph, 2010). It has allowed a separation of the problem of electricity supply and shortages from the problem of deteriorating finances in state-owned utilities, thus reinforcing the 'electricity-politics nexus' and circumventing the issue of cost-reflective pricing (Joseph, 2010).22 To generalize, it has also been argued that in countries like India, reform processes evolve alongside political processes which reshape themselves to maintain the status quo, and this situation continues to counter the effectiveness of attempted reforms (Dubash, 2011).

Table 2.1: Structure of the Electricity Sector in Developing Countries

\begin{tabular}{|c|c|c|}
\hline & Structure of Electricity Sector & $\begin{array}{l}\text { Number of } \\
\text { Countries }\end{array}$ \\
\hline A & Vertically Integrated Monopolies & 79 \\
\hline B & Vertically Integrated Monopolies with IPPs & 36 \\
\hline C & $\begin{array}{l}\text { Single Buyer as National GenCo, TransCo or DisCo OR a Combined National } \\
\text { GenCo-TransCo or TransCo-DisCo + IPPs }\end{array}$ & 16 \\
\hline D & $\begin{array}{l}\text { Multiple DisCos and GenCos, including IPPs, TransCo as Single Buyer with } \\
\text { Third Party Access }\end{array}$ & 6 \\
\hline$E$ & $\begin{array}{l}\text { Power Market of GenCos, DisCos and Large Users, TransCo and } \\
\text { Independent System Operator }\end{array}$ & 13 \\
\hline & \multicolumn{2}{|l|}{ Source: Gratwick and Eberhard (2008); Besant-Jones (2006) } \\
\hline \multicolumn{3}{|c|}{ Note - GenCo, TransCo, DisCo refer to generation, transmission and distribution companies. } \\
\hline \multicolumn{3}{|c|}{$\begin{array}{l}{ }^{19} \text { Used here to refer to the supply of uninterrupted electricity and universal access. } \\
{ }^{20} \text { Own-generation (by industry). } \\
{ }^{21} \text { In India, the Value of Lost Load (VOLL) was estimated by the Central Electricity Regulatory Commission at Rs. 34-122 per } \\
\text { KWh, compared with the weighted average of short-term prices on power exchanges at Rs. } 4.96 \text { for the same year (CERC, } \\
2013) \text {. This may well be an underestimate due to the lack of reliable data. Captive capacity is believed to account for a third of } \\
\text { India's total installed capacity of roughly } 200 \mathrm{GW} \text {. } \\
{ }^{22} \text { This has led to a situation where industries can generate independently, whereas state utilities which serve residential and } \\
\text { agricultural consumers continue to struggle with cost-reflective pricing. }\end{array}$} \\
\hline
\end{tabular}



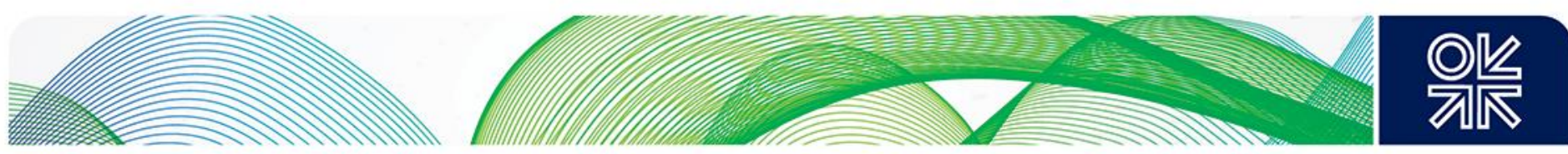

As a result, despite over two decades of reform involving the standard model and its variations, few developing countries have successfully replicated the standard model to the extent of full liberalization - which is seen, for example, in the UK (Table 2.1). Latin American countries have arguably gone the furthest in terms of the creation of wholesale markets and regional market integration (Raineri et al., 2013). However, for developing countries in Asia and Africa, the reform has led to hybrid structures, or vertically integrated structures with some private participation in generation. For instance, India has a hybrid version of the standard model; state-owned utilities exist alongside private companies in generation and distribution, and power is mostly traded through Power Purchase Agreements while a relatively small but growing proportion of electricity is traded on short-term markets through power exchanges and bilateral contracts. ${ }^{23}$ However, a substantial proportion of the population has partial or no access to a continuous supply of electricity. Most African developing economies have adopted the IPP element of the standard model alongside state-owned, vertically integrated entities (Gratwick and Eberhard, 2008).

Figure 2.2: The Standard Model as Applied to India
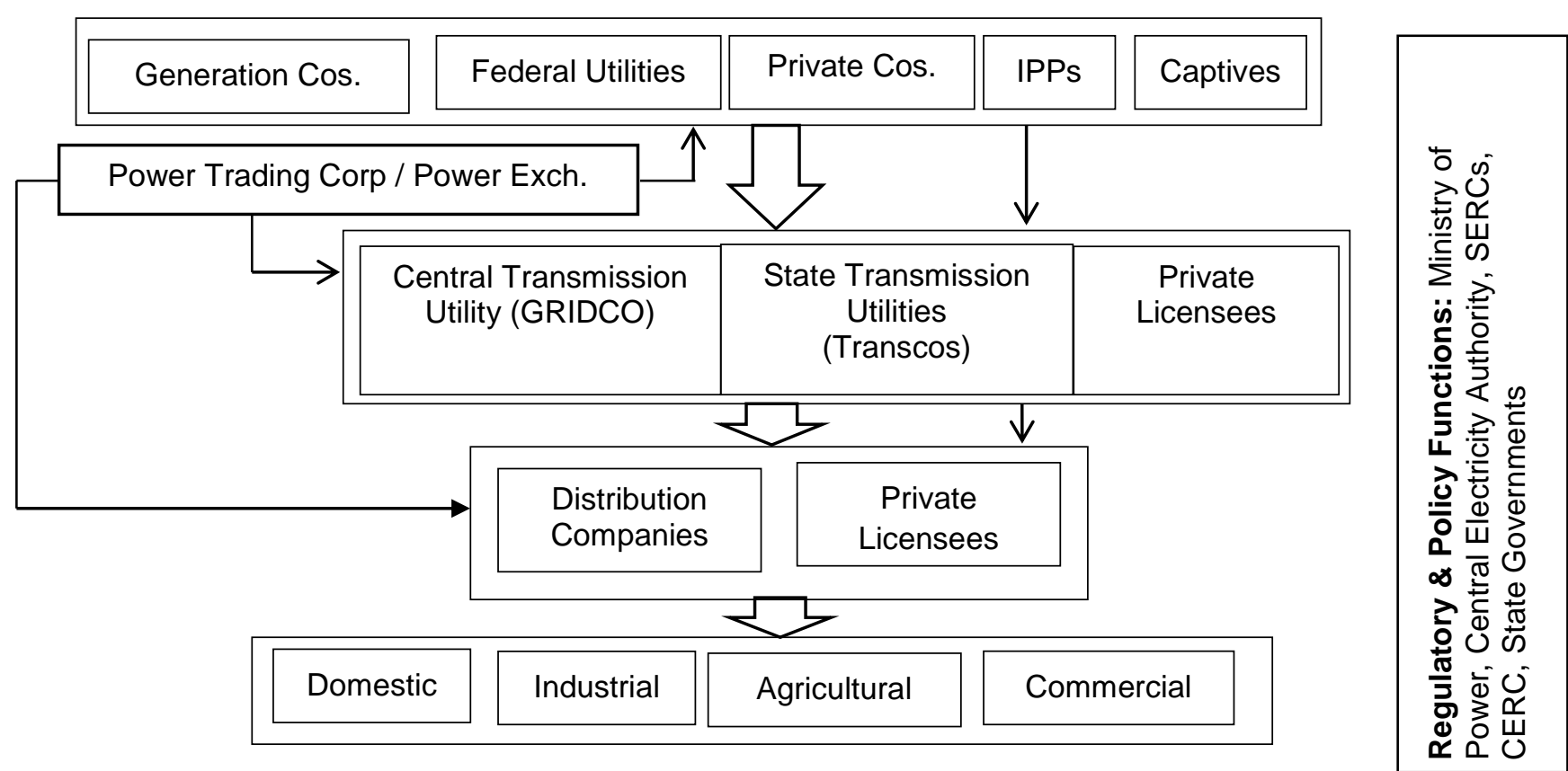

Source: Singh (2010)

Figure 2.2 depicts the outcome of the standard model as applied to India's power sector. The top row represents generation - comprising a mix of federal and state government utilities, private and privatized companies, IPPs, and captive generators. Two power exchanges and the state-owned Power Trading Corporation of India (second row) facilitate a small percentage of market-based trading, whereas the majority of trade is carried out through longer-term Power Purchase Agreements. The third and fourth rows depict transmission and distribution companies (retail supply and distribution are integrated) which include government (federal and state)-owned companies as well as private licensees, and the last row shows categories of consumers.

\footnotetext{
${ }^{23}$ Approximated at $11 \%$ of the total electricity market. The short-term power market in India covers contracts of less than a year's duration transacted through trading licensees, power exchanges, direct trading between distribution companies, and through 'unscheduled interchanges'. (CERC, 2013).
} 

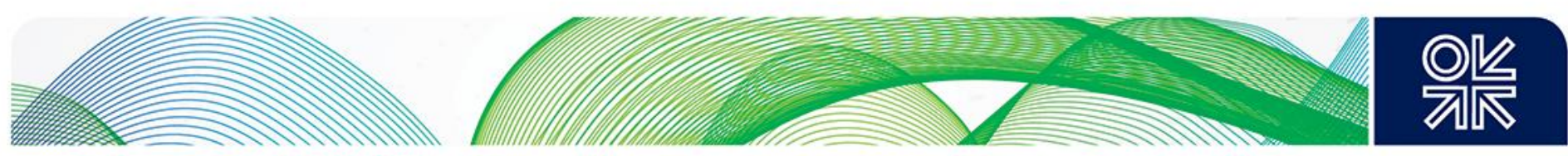

These intrinsic obstacles to the implementation of reform via the standard model have in the past been regarded as a part of the evolution of the reform process in developing economies, which could be overcome through the gradual strengthening of institutional capacity and encouragement of competition in the sector. However, recent experience in the developed world (particularly in the EU, specifically the UK) has led to questions over the underlying logic of the model of electricity sector liberalization in a future where renewables are intended to play a greater role. This arguably presents a whole new set of challenges for policymakers in developing economies. Further, it is argued that the hybrid structures (which have emerged out of efforts to implement the standard model of reform in developing economies) have created further ambiguity over residual decision-making powers in relation to planning, investment, and the procurement of new capacity (Gratwick and Eberhard, 2008).

\section{The Problem with the Standard Model: Economics versus Policy ${ }^{24}$}

Why has the relevance of the standard model of reform (based on electricity market liberalization) recently been brought into question? There are two dimensions to this: one based on the economics of electricity markets and the other on broader national and regional targets on emissions reduction, which primarily pertains to the EU. These dimensions have exposed some inherent contradictions within the standard model.

\subsection{Price setting in the standard model and the issues of incorporating renewables}

First, briefly summarizing the economics from recent literature; ${ }^{25}$ electricity prices in liberalized wholesale markets are set according to the system marginal cost, that is, the short-term marginal cost of the last (and, following the merit order, typically most expensive) plant that is required to be brought onto the system in order to meet demand. Generation companies are therefore incentivized to compete on costs, as those with lower short-term marginal costs than the system marginal cost will gain from this. These markets are also referred to as 'energy only markets' in that the incentives to encourage more investment in generation are considered as being built into the price signals, rather than through externally imposed generation adequacy standards ${ }^{26}$ (UKERC, 2010). Spikes in energy prices caused by plant scarcity are attenuated by price sensitivity, and the value that different classes of demand place on an additional MWh of supply is exposed (UKERC, 2010). In this way, the market effectively determines how much generation capacity is required (UKERC, 2010). ${ }^{27}$

Energy-only markets are largely designed to match the characteristics of conventional (fossil) fuel generation and investment (Keay et al., 2013a; 2013b). If we then consider renewable energy particularly wind energy, upon which much emphasis is currently being placed, worldwide - this has very high capital costs but a zero marginal cost of operation. Further, wind energy is intermittent, and while studies ${ }^{28}$ show that during periods of abundant availability supply could be sufficient to match demand, the intermittency of wind energy requires that 'backup' forms of generation be available to ensure a continuity of supply during periods of low availability of wind. It is also important that this

\footnotetext{
24 This section draws from literature previously published by the OIES, specifically Keay et al. (2013a; 2013b); Buchan and Keay (2014); Keay (2013a; 2013b; 2009), Robinson (2013), and Rhys (2013).

${ }^{25}$ Based primarily on the UK electricity market and the references in footnote 24.

${ }^{26}$ Such as by a government or regulator.

${ }^{27}$ As referred to earlier, there has been criticism of the effectiveness of markets in promoting investment in generation.

${ }^{28}$ Again, based on the UK market.
} 

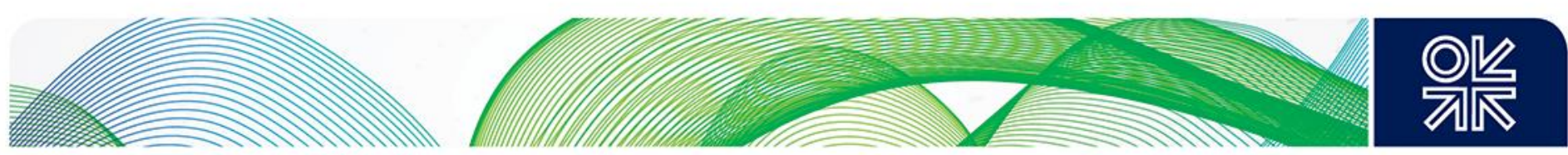

backup generation is flexible and able to adjust quickly to demand, thus making it inevitable that it will primarily be fossil fuel-based. ${ }^{29}$ Two problems emerge here: first, in order to encourage the highly capital intensive investments that are required in wind (and indeed other renewables such as solar) governments have to offer support schemes such as Feed-in Tariffs (FiTs) or other forms of subsidies which essentially undermine the role of the liberalized market in setting prices and in motivating investment.

And second, the unpredictability of wind energy in particular implies that market prices will either be set equal to zero marginal costs (during periods when there is abundant wind) or conversely, they will have to be set at extremely high levels at times when wind is low or unavailable (in order to allow backup generators to recover their costs and justify capital investments in backup generation in the first place). This could imply shorter periods of zero or low prices and longer periods of very high prices (Keay et al., 2013a; 2013b); these high prices would be difficult to justify to a public which already questions high energy prices, as market liberalization was largely sold to them on the basis of competitive prices. ${ }^{30}$ More importantly, if renewables are integrated into wholesale markets in their current form, they may not even recover their fixed costs (without extra-market payments) because when they run, prices would be low or zero (Robinson, 2013).

It has also been argued that support schemes such as FiTs discourage innovation through 'cherry picking technologies' thereby impeding reductions in the capital costs of renewable energy (Keay et al., 2013a; Keay, 2013b). Arguably, even if the technical costs of renewable energy were to decline over time with technological advances, system or resource costs could continue rising, as the resource may tend to get costlier the more it is exploited (Keay, 2013a). ${ }^{31}$ This reflects the inherent contradiction in the use of markets (in their current form) in electricity provision, in a system which needs to rely increasingly on renewable energy sources. ${ }^{32}$

The solutions that have been advocated to this problem can essentially be categorized into two 'camps': the greater use of markets to ensure investments in both renewables and backup generation (that is, the setting up of separate capacity and balancing markets in addition to energy-only markets), or conversely, the establishment of a single-buyer agency to coordinate the integration of renewables into the electricity sector - which arguably amounts to a return to central planning (Keay et al., 2013a; 2013b; Newbery, 2013).

\footnotetext{
${ }^{29}$ Based purely on cost effectiveness, in many countries this would be coal. However, coal is being deliberately discouraged in the EU due to the obvious environmental concerns. Hydroelectricity could provide another alternative, but this would require the country in question to have adequate and accessible hydroelectric resources. Nuclear electricity can provide some flexibility, but many developing countries, such as India, face public opposition to nuclear energy. This leaves gas as the primary backup fuel in many EU countries including the UK - however, in countries like Germany, it could be coal, depending on the price and flexibility of plant.

${ }^{30}$ It must be noted here that competitive prices do not necessarily equate to lower prices, if prices at the outset are below costs. However, the broad expectation was that privatization and restructuring would lead to better operational efficiencies, and that these gains would at some point be passed on to consumers.

${ }^{31}$ In other words, the 'low hanging fruit' or the easiest and best sites for the development of renewable energy are likely to be used up early on (Keay, 2013a). Resource costs are geographical - they are determined by the quality of the resource, closeness to demand centres and transmission infrastructure, environmental sensitivity, and so on (Keay, 2013a).

${ }^{32}$ The contradiction can also be framed in terms of having markets, but not allowing them to work, as governments continue to subsidise certain technologies.
} 

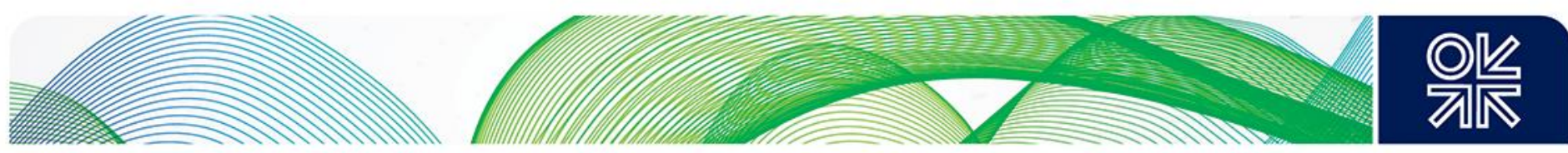

\subsection{The effects of emissions reduction targets on the standard model}

The second dimension that has led to a questioning of the relevance of the standard model of reform on a wider (even international) scale is the existence of national as well as regional emissions reductions targets, and the conflicts between market mechanisms and the nature of these targets that have led to general ambiguity and uncertainty over future policy. An illustration of a relatively ambitious national target can be seen in the UK's 2008 Climate Change Act; this aims at achieving an 80 per cent reduction in greenhouse gas emissions from the 1990s baseline by 2050, and meeting 15 per cent of the UK's energy demand from renewables by $2020 .{ }^{33}$ The electricity sector (as stated earlier) has been specifically targeted, as it provides the most direct way of influencing emissions (Keay, 2009). Section 3.1 has already debated the issue of whether market liberalization can deliver the required investment in renewables and backup generation.

A prominent regional target is the EU's climate and energy package which sets binding legislation for its '20-20-20' targets - namely, a 20 per cent reduction in EU greenhouse gas emissions from 1990 levels, raising the share of EU energy consumption from renewables by 20 per cent, and a 20 per cent improvement in the EU's energy efficiency - all to be achieved by 2020 , with a longer term goal of an 80-95 per cent reduction in emissions by $2050 .{ }^{34}$ This was to be achieved through a set of policy tools based on greater market integration ${ }^{35}$ combined with nationally-driven targets on emissions reduction.

Although at first glance the national and EU targets appear complementary, they may actually be conflicting (Keay, 2013b; Buchan, 2013). First, EU policy appears to be aiming at greater market integration and competition to achieve its targets. But for EU countries such as France, where 75 per cent of electricity is generated from nuclear energy and is low-priced by European standards, ${ }^{36}$ greater market integration with the EU is likely to led to higher prices (at least initially), which is unlikely to be accepted by French consumers who initially had to pay higher tariffs to finance the early capital investments in nuclear energy (Percebois, 2013). Also, there is some ambiguity over the regulations under EU policy against national governments providing 'state support' to emissions reduction schemes that are unsanctioned at the regional (EU-wide) level, as this could be seen as undermining the principle of competitive markets ${ }^{37}$ (Keay, 2013b). 'Large markets', achieved through cross-border market integration, have in fact been proposed in the literature as a way of ensuring greater flexibility in the response of generation to demand, as a larger pool of plants is available to call upon for dispatch (Riesz et al., 2013).

For the UK, this conflict between levels of policymaking (national and EU level) feeds into the central planning versus markets debate, and contributes to ambiguity over future national policy direction which, in turn, contributes to the holding back of investments in generation via electricity markets. This

\footnotetext{
33 This will require the electricity sector to be almost totally decarbonized by 2030 .

34 Targets for beyond 2030 (a 40\% reduction) were set by the EU in January 2014, although it has been argued that these are insufficient to achieve a reduction of 80-95\% in emissions by 2050 (Buchan and Keay, 2014).

${ }^{35}$ See http://ec.europa.eu/clima/policies/package/index en.htm for details. The EU Emissions Trading System has been widely criticized for its ineffectiveness.

${ }^{36}$ Price controls exist for households (Percebois, 2013).

37 That is, setting the emissions target but leaving the choice of technology or method to the market. Efforts have been made to resolve this - guidelines published in 2014 mention feed in premiums (over pool prices) as opposed to FiTs, and auctions for new renewables capacity. See http://ec.europa.eu/competition/sectors/energy/legislation en.html
} 

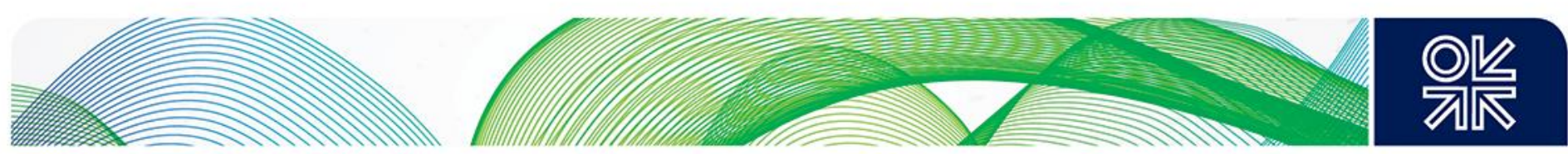

also constitutes a serious policy problem for the UK, given its national targets on emissions reduction. It has in fact been argued that it is a contradiction to want greater electricity market integration whilst at the same time allowing autonomy to national governments in the selection of their energy mix (Percebois, 2013).

\section{The Implications for Electricity Reform in Developing Countries}

Some may argue that the experience of electricity reform in developed economies as described above, particularly in relation to the effects of renewables targets and emissions reduction schemes on the standard model, demonstrates a need to return to the drawing board; others, that this is yet another stage in the evolution of market processes. The relevance or urgency of this policy issue in developing countries - which have argued that greater responsibility should be placed on the developed world in terms of creating and participating in solutions ${ }^{38}$ to climate change mitigation - is one question that has arisen. Although this argument is justifiable on many grounds, there are two important points, below, which contradict any policy stance that completely abdicates responsibility on the part of developing countries.

First, for developing countries, where often the amount of effort required to bring about a policy outcome can be immensely disproportionate to the value of that outcome (Sen and Jamasb, 2013),39 the future implications of the selection of a particular policy path can turn out to be significant and expensive. This effort requires proactive and decisive policy choices in the immediate or short term. And second, given that developing nations stand to lose the most from climate change in terms of its human costs (IPCC, 2007), it can be assumed that at some point in the future, the citizens of democratic developing countries will hold their governments accountable for inaction - in other words, climate policy could become as much a political issue in the future as cost-reflective pricing is now. Indeed, many governments have, in recognition of this possibility, voluntarily undertaken programmes on climate change mitigation; for instance, India (the world's largest democracy) in 2010 launched its National Action Plan on Climate Change (NAPCC). The NAPCC is, however, seen as separate from electricity sector reform per se (unlike the case for similar schemes in the EU and the UK), although there have been efforts to integrate renewables (primarily solar and wind) into grid-connected supply (which is primarily based on coal-fired generation) facilitated through the power exchanges. Nevertheless, Table 4.1 below shows that any serious effort at decarbonization would need to have the electricity sector at its core, as electricity comprises the largest source of emissions across the board, and hence provides the most direct way to bring about an emissions reduction (Keay, 2009).

Given this need for heightened attention by policymakers to electricity issues, and the problems associated with the standard model of reform discussed thus far, what are the main challenges that developing countries face with respect to electricity sector reform going forward? Broadly, there are eight areas or issues

\footnotetext{
${ }^{38}$ Particularly solutions which involve binding targets and financial commitments. A prominent strand of the debate on decarbonization is not whether developing countries should decarbonize, but the question of who should pay for this decarbonization.

${ }^{39}$ Referring, for instance, to the difficulties governments have had with implementing cost-reflective pricing, despite the last two decades of electricity reform.
}

May 2014: Divergent Paths to a Common Goal? An Overview of Challenges to Electricity Sector Reform in 10 Developing versus Developed Countries 

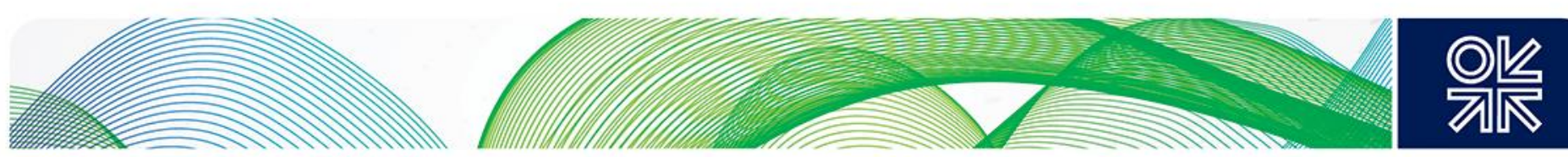

Table 4.1: Per Capita Emissions by Sector, 2010 (kg of $\mathrm{CO}_{2}$ per capita)

\begin{tabular}{|l|r|r|r|r|r|r|c|}
\hline & $\begin{array}{c}\text { Electricity } \\
\text { and Heat } \\
\text { Production }\end{array}$ & $\begin{array}{c}\text { Other } \\
\text { Energy } \\
\text { Industry } \\
\text { Own Use }\end{array}$ & $\begin{array}{c}\text { Manufacturing } \\
\text { Industries } \\
\text { and } \\
\text { Construction }\end{array}$ & Transport & Residential & Other & $\begin{array}{c}\text { Total } \mathbf{C O}_{2} \\
\text { Emissions } \\
\text { from Fuel } \\
\text { Combustion }\end{array}$ \\
\hline OECD & 4,007 & 558 & 1,423 & 2,699 & 797 & 1,408 & 10,096 \\
\hline UK & 2,873 & 519 & 822 & 1,919 & 1,325 & 1,643 & 7,776 \\
\hline USA & 7,448 & 845 & 1,893 & 5,229 & 1,038 & 1,897 & 17,312 \\
\hline India & 748 & 52 & 342 & 138 & 64 & 108 & 1,388 \\
\hline China & 2,659 & 205 & 1,734 & 382 & 225 & 416 & 5,395 \\
\hline Brazil & 230 & 129 & 585 & 852 & 87 & 194 & 1,989 \\
\hline Africa & 414 & 39 & 138 & 215 & 56 & 104 & 910 \\
\hline Middle & 2,715 & 786 & 1,577 & 1,651 & 623 & 829 & 7,559 \\
East & & & & & & & \\
\hline
\end{tabular}

Source: Keay (2009); IEA (2008)

\subsection{The future of coal in electricity market design}

The role of coal in electricity market design is not much of an issue in many developed countries, as conscious policy efforts are being made to 'back out' coal-fired generation through decommissioning. ${ }^{40}$ However, it is now certain that pending any radical changes in policy direction, coal will continue to form a major proportion of the energy mix, and of electricity generation, in developing countries - primarily China and India. Figure 4.1 shows this for the year 2035 based on the IEA's New Policies Scenario.

If developing countries were to continue towards full electricity market liberalization (assuming that the problem of cost-reflective pricing and the finances of utilities were successfully addressed along the way), then the system could arguably be successful in balancing electricity generated from renewables with electricity from conventional (fossil) fuels. The irony here is that this backup generation is likely to be cheap coal - environmentally far more damaging than gas, which is its closest substitute. Appendix A of this paper depicts some estimates of the average levelized costs (US\$/Megawatt Hour) for different forms of generation. ${ }^{41}$ While the capital costs for gas-fired generation are relatively lower than those for coal, gas involves a significant investment in the building and operation of 'systems' infrastructure, which does not exist in developing economies such as India. India, however, has large and abundant reserves of conventional coal. Therefore, assuming the absence of any binding carbon price, and given the cost effectiveness of coal, the future of electricity markets in developing economies could consist of renewables with coal - constituting a significant policy contradiction.

\footnotetext{
${ }^{40}$ This refers specifically to EU countries. Despite this, coal has made a comeback in some EU countries. In Germany, the shutting down of nuclear power stations has ironically led to the resurgence of coal and, even worse, of lignite (Rhys, 2013). Outside the EU, the USA is still a heavy user of coal, with the EIA forecasting coal use to increase to roughly $35 \%$ of the energy system in 2040.

${ }^{41}$ Data from the EIA - based on US generation as a representative illustration.
}

May 2014: Divergent Paths to a Common Goal? An Overview of Challenges to Electricity Sector Reform in 11 Developing versus Developed Countries 

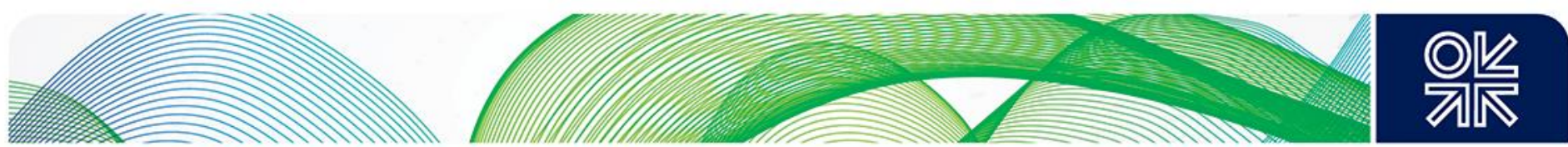

Figure 4.1 Percentage Shares of Fuel Sources in Electricity Generation, 2035

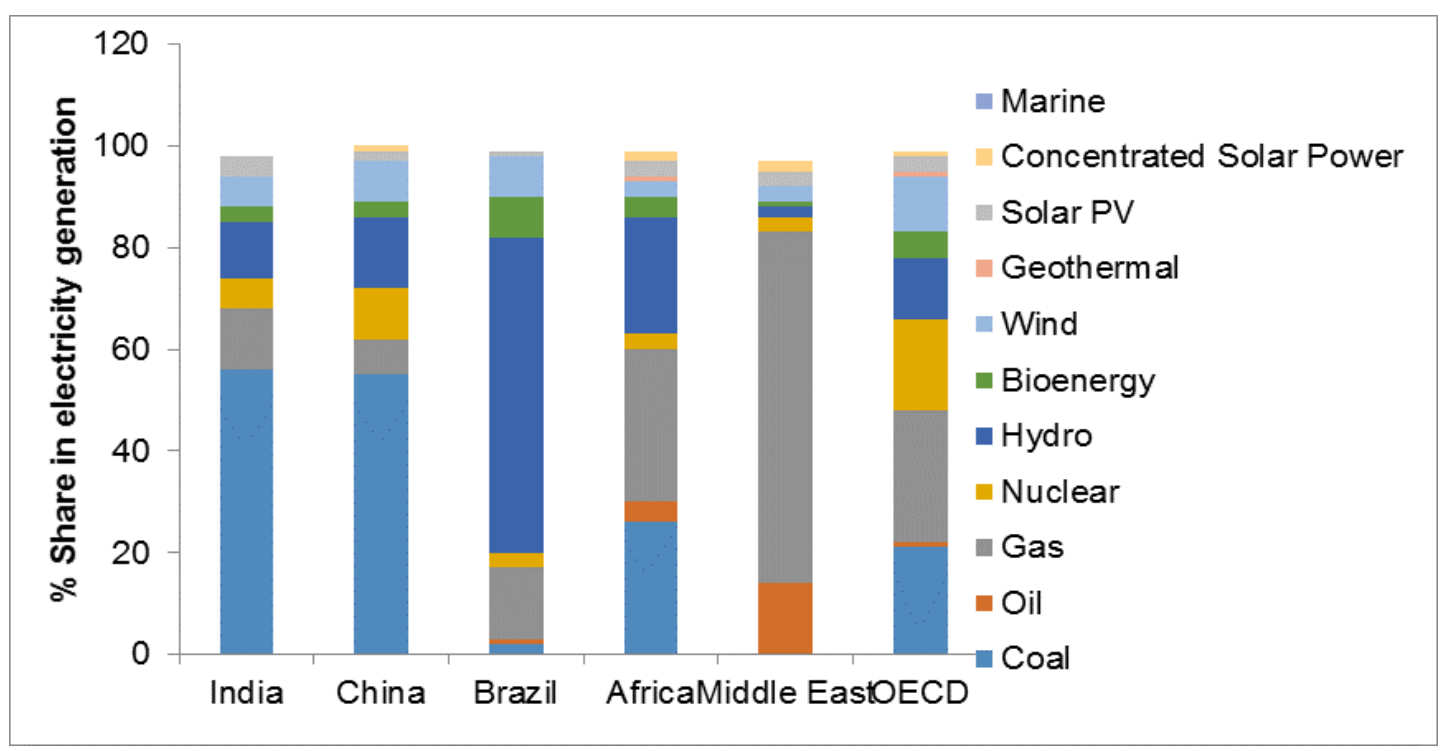

Source: IEA (2013) $)^{42}$

The evidence suggests that this is already happening; in India (where complete electricity market liberalization has not yet been carried out) the government recently announced four 'Ultra Mega Power Plants' of 500 MW each based on solar energy alongside plans to construct several 'Ultra Mega Power Plants' based on coal. ${ }^{43}$ There is, however, an inherent contradiction to the possibility of a market comprised of renewables and coal (or fossil fuels in general) in that under a system of liberalized markets in their current structure, the use of fossil fuels as backup generation would not earn back the fixed costs; this constitutes a disincentive to investors to build backup coal generation. In other words, it brings into question whether a combination of fossil fuels and renewables could work at all under the system of liberalized markets. This reduces to the problem (familiar to developed economies) of investment.

Despite these issues relating to the use of coal in electricity markets, it is by no means certain that a central planning agency in a developing economy, even if it had the authority, would advocate the exclusion of coal from the energy mix of that economy, or would indeed be successful in any attempts to do so. For instance, in India, gas-fired generation has failed to take off as a substitute for coal despite nearly two decades of efforts in the promotion of domestic gas production through a system of auctioning licences for exploration and production, while power from LNG is seen as an expensive option, as energy is largely viewed as a balance of payments problem. The availability of cheap coal on the international market, as a consequence of EU targets on emissions reduction and US energy independence through shale, is further likely to strengthen the case for coal in developing countries with acute energy shortages, issues relating to poverty and equity, and no binding targets on decarbonization. Future electricity market design as it pertains to developing countries will therefore need to account in some way for the role of coal. This is significant from a holistic perspective as initiatives on backing out coal in the EU and other parts of the world would be offset by a greater burning of coal in developing Asia.

\footnotetext{
${ }^{42}$ Figures do not add up to $100 \%$ in all cases - this is due to a lack of data.

${ }^{43}$ It could be argued there that solar energy is matched more closely with patterns of demand than wind. For instance, the availability of solar power is greatest in the middle of the day, which is also when demand (primarily from businesses and industry) is high. However, this does not completely preclude the negative environmental consequences of burning more coal.
} 

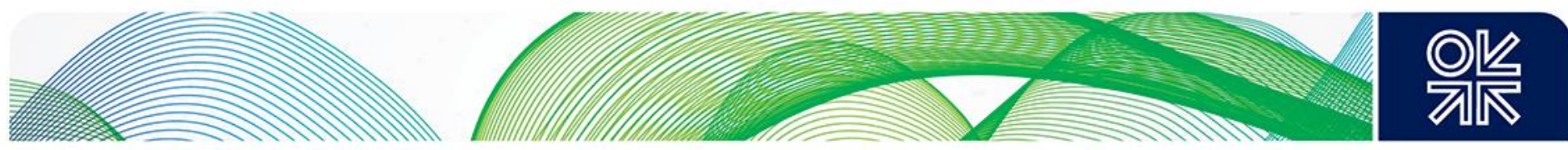

A final dimension to the issue of coal in future electricity market design is the role of multilateral financial institutions in energy sector lending, specifically in relation to coal-fired power, and whether this could in any way influence the design of electricity reforms; this could be analogous to the first 'wave' of reforms in the 1980s and early 1990s. International Financial Institutions (IFIs) accounted for roughly US $\$ 51$ billion in the financing of coal-related projects from 2007-13. ${ }^{44}$ Some multilateral finance institutions have announced that they will cease funding inefficient ${ }^{45}$ coal projects. ${ }^{46}$ Interestingly, by some accounts, bilateral finance to coal-fired power from country-specific institutions, such as Exim banks and export credit agencies, has formed the larger proportion of IFI financing over the last five years. ${ }^{47}$ The impact of a reduction in IFI financing to coal-fired power projects on future policy direction in developing economies is therefore important - particularly for China and India, the two largest coal consuming developing economies, as depicted in Figure 4.1. However, one report suggests that China can finance coal projects on its own, and India has relied on export credit only in a few cases. ${ }^{48}$

\subsection{Determining the optimal level of investment in generation}

As stated earlier, investment is as much a problem in developing economies as it is in developed economies. The nature of the investment problem is, however, slightly different in each case: in developed economies, the investment problem is largely one of keeping the lights on, whereas in developing economies, it is additionally one of turning the lights on.

While energy-only markets focus on short-term marginal costs, they do not separately take into account long-run marginal costs, which arguably are directly related to investments in generation capacity. Further, in developed economies, incentive structures need to ensure an optimal level of investment. The significance of this can be demonstrated through the case of FiTs for renewable energy in Spain, where incentives to increase investments in generation without regard to actual requirements led to excess and underutilized capacity; this came at a high financial cost to the government, which had to help finance a larger than expected 'tariff deficit', which will eventually be paid by customers through higher tariffs in the future. ${ }^{49}$ In developing economies such as India, where (official) electricity shortages run at $9-11$ per cent, ${ }^{50}$ with a rapidly growing economy and a large

\footnotetext{
${ }^{44}$ See www.huffingtonpost.com/jake-schmidt/too-much-public-funding-i b 4314333 .html.

${ }^{45}$ This has caused some controversy in terms of the polluting effects of technologies. For instance, in 2008 the World Bank contributed finance to India's Tata Mundra Power Plant on the basis that the plant's 'supercritical' technology could burn coal more efficiently than conventional technologies.

${ }^{46}$ This only applies with some exceptions and some ambiguities - for instance, the Asian Development bank continues limited support to coal projects (see www.adb.org/sectors/energy/policy) and in December 2013 sanctioned a US $\$ 900$ million loan to the Jamshoro coal fired power project in Pakistan (see www.adb.org/projects/47094-001/main).

${ }^{47}$ Again, with some exceptions - for instance the US Exim bank has recently excluded coal financing from its funding guidelines. For an interesting discussion of this issue see www.huffingtonpost.com/jake-schmidt/too-much-public-fundingi b 4314333.html. (Note that the data contained in the link is unverified by the author of this paper).

${ }^{48}$ Yang and Cui (2012); Drajem (2013).

${ }^{49}$ As against an expected capacity addition of $400 \mathrm{MW}$ of solar PV, the actual capacity addition was more than $4500 \mathrm{MW}$. The tariff deficit was initially financed by the electricity companies, who securitized it, passing the risk to financial markets. Eventually the government agreed to guarantee some of the tariff deficit, and this in turn added to their debt obligations to international financial markets and, indirectly, to their cost of financing the public debt. See Robinson (2013).

${ }^{50}$ This represents the percentage of grid-connected consumers that are denied access to electricity at any point of time.
}

May 2014: Divergent Paths to a Common Goal? An Overview of Challenges to Electricity Sector Reform in 13 Developing versus Developed Countries 

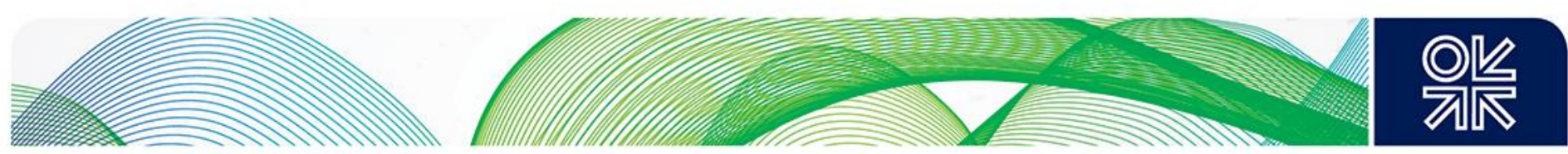

proportion of the rural population dependent on non-commercial fuels (such as firewood), ${ }^{51}$ optimal levels of investment are arguably secondary to urgently ramping up investment more generally, subject to the extent to which expected increases in consumption may in the future be offset by gains in energy efficiency.

Indeed, the problem of investment again illustrates the contradictory nature of policy in electricity. In developed countries the concern is whether markets will deliver investments in renewables and backup generation, or whether a single buyer agency should instead take on the task. In developing economies, such as India, the single buyer (central planning) model has arguably already failed to deliver adequate investment in both conventional and renewable generation.

India, for instance, provides an illustration of some of the issues related to investments in renewable generation in developing countries. The Indian government in the 2000s attempted to stimulate investment in wind through a fiscal subsidy which incentivized profit-making businesses ${ }^{52}$ to invest in wind turbines by allowing them to write down 80 per cent of costs as depreciation expenditure, hence reducing their income tax liability. Although this led to substantial investments in wind capacity, actual generation was negligible. ${ }^{53}$ The government then attempted to address this through the provision of a 'generation based incentive' wherein wind generators were paid Rs. 0.50 per KWh for electricity that was actually sold to grid-connected state utilities. This scheme was withdrawn in April 2012, presumably due to its financing costs, and then reinstated in August 2013 on the basis that wind generators who claimed the accelerated depreciation provision would not be eligible for the generation-based incentive. This approach made a distinction between the investors who built wind turbines, and those who generated and sold wind to utilities. It remains to be seen whether this separation will result in more investment or less, and the outcome depends to a large extent on gridconnecting infrastructure. ${ }^{54}$ However, under a system of liberalized markets, generators would gain large profits as their marginal costs would be very low or zero.

The lack of investment in conventional (fossil fuel) generation is related very closely to upstream exploration and production policy, and in particular to pricing. For example, the fiscal regime for exploration and production of gas in India is relevant to the substitution of coal with gas in power generation. ${ }^{55}$

Two key questions pertaining to the future of electricity market reform in developing economies are therefore: firstly what constitutes an optimal level of investment for different developing economies, and secondly which mechanisms are most likely to bring about this investment. The policy problem here is a complex one; it requires a solution that (a) ensures universal access to electricity, (b) is based on cost-reflective pricing, (c) integrates renewables onto the system, and (d) is free from political appropriation. The design of investment mechanisms for developing economies necessitates a closer look at the hybrid market structures that have emerged in these economies - in terms of identifying all these structures and working out how they could function in conjunction with each other

\footnotetext{
51 These sections of the population cannot afford to pay cost-reflective prices. Subsidies have thus far proved regressive, largely benefiting the rich, and programmes of direct cash transfers have also run into numerous obstacles, and have stalled.

52 Across all economic sectors.

${ }^{53}$ Businesses largely used the incentive as a 'balance sheet investment'. Often, the lack of grid connectivity contributed to the failure to generate electricity.

${ }^{54}$ This would enable investors to sell electricity to local utilities at zero marginal costs.

55 The upstream pricing regime ultimately sets electricity prices downstream.
}

May 2014: Divergent Paths to a Common Goal? An Overview of Challenges to Electricity Sector Reform in 14 Developing versus Developed Countries 

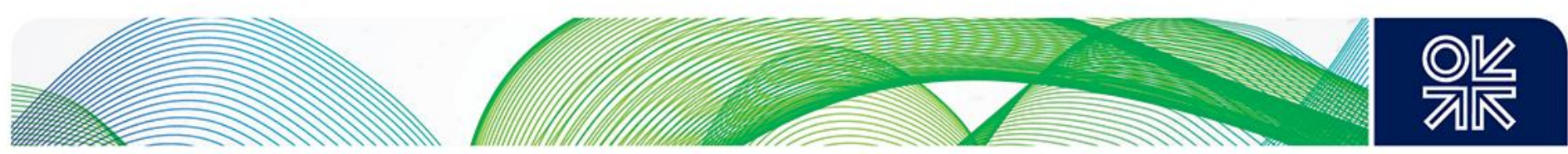

towards a defined set of goals. Essentially, this strategy could comprise a looser, less sophisticated approximation of the 'multiple markets' solution being considered in the UK. ${ }^{56}$

\subsection{The potential for fuel substitution in electricity generation}

A 'bridge' between policymaking in electricity and that in the upstream sector (pertaining to fossil fuels) in developing economies could be facilitated through estimating the elasticity of substitution among fuels in power generation (measuring how the use of these fuels varies as their relative prices change). This would, firstly, allow useful comparisons with developed economies, and secondly, help draw policy implications in advance of adopting particular reform measures. For instance, if the elasticity of fuel substitution was very low for any given developing economy, it could follow that policy measures towards decarbonization or reforms on pricing would have to be structured much more effectively or stringently in order to bring about any real changes. This could help in evaluating the potential of the 'markets versus central planning' approach. ${ }^{57}$

\subsection{Rural electrification}

The issue of rural electrification adds a new dimension to the debate over the design of electricity systems - the absence of electricity in rural areas is still a very real and pervasive problem in developing countries. In India, for instance, despite several parallel state-run rural electrification programmes, an estimated 77 million people still use kerosene for lighting, while approximately 40 per cent of the rural population lacks basic access to electricity (Census, 2011). Electrified rural households also face hours of power cuts on a daily basis. India's Ministry of Power estimates that levels of rural electrification stand at 94 per cent; 58 this, however, is subject to a narrow definition of rural electrification, which includes the electrification of 10 per cent of households in a village, basic transformer infrastructure, and electricity provision in public institutions (such as schools). Additionally, there are an estimated 9,000 villages where grid connectivity has proved almost impossible (and will perhaps continue to do so) due to their remoteness of location (CSE, 2013). Electricity sector reform via both market structures as well as direct government intervention have arguably completely bypassed these areas in rural India, where the primary problem remains that of investing in basic infrastructure, grid connectivity, and the development of self-sustaining electricity systems. The positive aspect of this problem is that it enables the adoption of renewable energy in electricity generation from the ground up - one solution being trialled in India is the development of 'mini grids' based on solar energy. However, in the absence of post-installation support, the main problems around these mini grids involve their continued maintenance and operation. Distributed generation comprises an important element of the study of rural electrification. The interface between

\footnotetext{
${ }^{56}$ In developed economies, the market based solutions being considered are: separate energy-only, capacity, and balancing markets working in conjunction with each other to achieve separate objectives. A market-based solution for developing economies such as India could require a mechanism that mimics this function for objectives (a), (b), and (c). The use of markets would per se fulfil objective (d) as one of the primary functions of markets is to facilitate solutions that are free from political appropriation or interference.

${ }^{57}$ That is, in determining which policy approach is likely to bring about a greater response in demand, given the elasticity of fuel substitution.

${ }^{58} \mathrm{See}$ www.cea.nic.in/reports/monthly/dpd div rep/village electrification.pdf.
}

May 2014: Divergent Paths to a Common Goal? An Overview of Challenges to Electricity Sector Reform in 15 Developing versus Developed Countries 

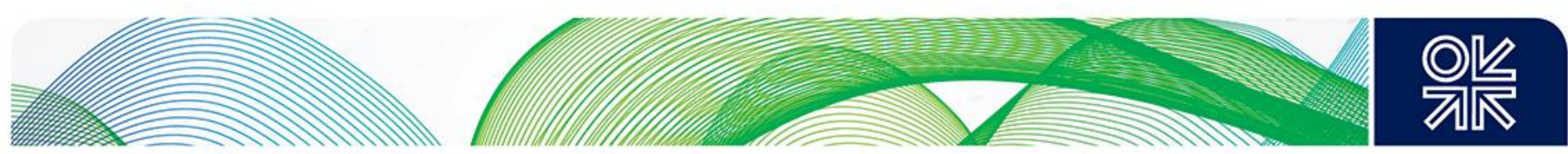

rural electrification and wider electricity market structures is generally an essential component of electricity market design in developing economies. ${ }^{59}$

\subsection{Infrastructure and smart grids - identifying the prerequisites}

Smart grid technologies have been held up as a solution to problems with the coordination between renewables and conventional backup fuels, as they will enable more efficient demand responses (through direct consumer participation) and lower system costs. The literature is ambiguous on whether liberalized markets or a vertically integrated monopoly are better suited to smart grid technology. Arguments for and against the two market structures appear to be related to two factors: technical efficiency and pricing. In terms of efficiency, it has been argued that smart grids working in conjunction with liberalized markets can function more efficiently, which will have the effect of reducing the costs of operation. ${ }^{60}$ However, the way in which these lower costs are then treated would be different in liberalized markets from what would happen in conditions of vertical integration or in a regulated monopoly. Under vertical integration, the benefit of the lower cost would go directly to the single agency and therefore would be easily identifiable - some form of regulation would then be necessary to pass it on to consumers (Green, 2010). Market liberalization could make it harder to organize and capture the benefits of lower costs from a smart grid, and there would also be more players seeking to discover those benefits (Green, 2010). ${ }^{61}$

What is less clear is how smart grids would work with the hybrid structures that exist in many developing countries. For instance India has, despite numerous existing impediments to basic policy reform, already developed a 'roadmap' for the future adoption of smart grids in collaboration with two institutions, the India Smart Grid Task Force, and the India Smart Grid Forum. The roadmap recognizes that in order to progress to even a basic stage of readiness for the implementation of trials, electricity sector reform is a prerequisite. Nonetheless it proposes a somewhat ambitious time period of five years ${ }^{62}$ to address many of these basic constraints such as: achieving universal access to electricity, ${ }^{63}$ reducing aggregate technical and commercial loses to 15 per cent, and a putting in place a 'lifeline' level of 8 hours of continuous power supply to all by 2017 (Gol, 2013). Yet, there is no clarity over the structures within which smart grids will be operated (that is, markets or via a central agency). The prerequisites for smart grids in electricity, taking into account the characteristics of the electricity sectors and the objectives of developing economies, therefore need to be more clearly defined.

\subsection{Cost reflective pricing - a continuing dilemma}

A fundamental issue in electricity market design in developing economies is the need for costreflective pricing. Developing countries continue to grapple with important distributional issues, and in

\footnotetext{
59 The key issue here is whether the private sector has an incentive to promote rural electrification, including maintenance ex post. A promising area of research is the participation of mobile phone companies in promoting rural electrification, as they have an interest in facilitating the use of electricity for charging phones.

${ }^{60}$ Costs are reduced under vertical integration as well.

${ }^{61}$ However, markets would be more likely to encourage innovation.

62 The entire period of the 12th Five Year Plan, which runs to 2017

${ }^{63}$ A goal that was previously set for 2012 , but failed to be achieved.
}

May 2014: Divergent Paths to a Common Goal? An Overview of Challenges to Electricity Sector Reform in 16 Developing versus Developed Countries 

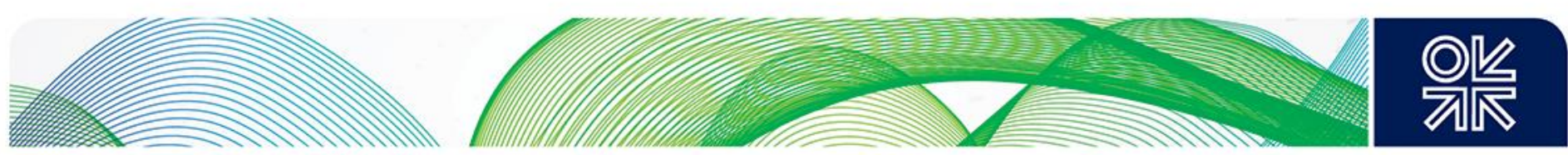

the past the direct use of the pricing system to address these issues has led to regressive outcomes, which have ended up benefitting the rich. ${ }^{64}$ Systems of direct cash transfers to eligible consumers have been proposed in many developing economies as a method of removing distortions in the pricing structure and of targeting consumers who are eligible for subsidies. However, in some countries such as India (which implemented the Unique Number Identification programme in 2011), these have failed to show results, and are on the verge of being shelved. 6566

\subsection{Regional electricity market integration - opportunities and implications}

An important aspect of the electricity sector going forward is the potential for regional electricity market integration in developing economies, and the implications of this in terms of electricity market design. Some such initiatives already exist in Asia, for instance, electricity trading in the Greater Mekong sub-region (GMS) - comprising Cambodia, Laos, Myanmar, Thailand, and the Yunnan Province and Guangxi Zhuang Autonomous Region of China - primarily takes place through bilateral exports. This project is supported by the Asian Development Bank (ADB), which finances clean energy projects (mainly hydro, in this case). The logic of inter-regional electricity trade in this case is presumably similar to that used in the EU - the promotion of clean energy, the reduction of costs in its provision, and the availability of electricity to countries that face a deficit. The ADB also supports regional electricity market cooperation in south Asia, and recently financed a cross-border $500 \mathrm{MW}$ HVDC interconnection between India and Bangladesh. India and Bhutan have a cross-border interconnection that will be augmented by 2020. India has also been involved in efforts to set up a multilateral SAARC ${ }^{67}$ Market for Electricity.

The implications of these policy initiatives, based on EU experience, are important; for example, it may be difficult to gain consensus on national and regional electricity sector objectives. Further, the experience in Latin America (through the SIEPAC and CAN regional markets) shows that one of the goals of regional electricity market integration, in addition to security of supply, is for governments to strengthen regional diplomatic relations, enabling greater political consensus (Raineri et al., 2013). In the case of Latin America, however, electricity market integration through liberalized markets is argued to have had a negative effect on this process, as countries which initially were a core part of the process (through direct bilateral and multilateral negotiations through their state electricity companies), have now been replaced by private companies, which have taken over the process (Raineri et al., 2013).

\footnotetext{
${ }^{64}$ This applies to all subsidies. A system of subsidies that is not explicitly targeted at the poorest (eligible) consumers ends up benefitting the relatively affluent. This has, for instance, been the case with petrol, diesel, and electricity subsidies in India, which have been uniformly subsidized (through the pricing system) rather than targeted directly at the eligible consumer.

65 In March 2014, the Indian Supreme Court ruled that it was not essential for consumers to hold a Unique Identification Number in order to receive subsidy payments.

${ }^{66}$ New solutions based on a modification of the standard model have been proposed for countries such as Mexico. See Bower and Fuentes (2014).

${ }^{67}$ South Asian Association for Regional Cooperation.
} 

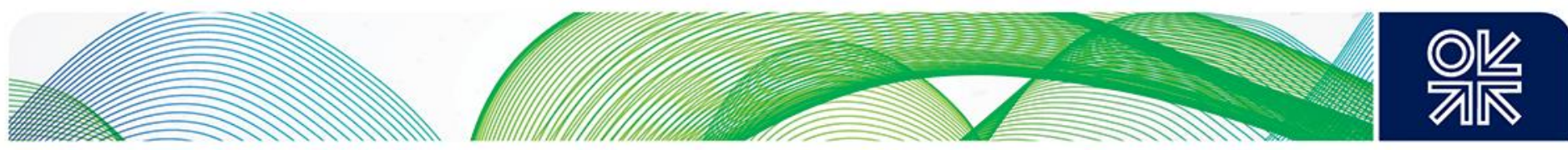

\subsection{Electricity sector reform and trade issues}

Trade issues are beginning to constitute a significant aspect of electricity sector reform in developing economies, particularly in relation to renewable energy. For instance in India, the proliferation of solar energy in electricity generation through the NAPCC rests heavily on the lower costs of using indigenously developed technology. India's National Solar Mission accordingly contains a clause mandating the use of indigenous technology in the development of solar energy projects. This has led to reactions from solar equipment exporting nations - the USA for instance made a complaint to the WTO over the issue of indigenous technology in 2013. This has also worked the other way around; China in 2012 approached the WTO over domestic content restrictions in the EU related to renewable electricity generation and FiTs, on the basis that these measures were inconsistent with the GATT and TRIMs. ${ }^{6869}$ The outcomes of trade disputes and the precedents that they set could arguably have an impact on the capital costs of renewable electricity in developing economies, and on government budgets. Trade issues in relation to electricity are therefore relevant considerations in designing electricity sector reforms in developing economies.

The issues described above are based to some extent on the differences between developed and developing countries when held up against the framework of the standard model of electricity reforms. We return to some of the broader analytical issues in the conclusion.

\section{Conclusion}

In conclusion, we would stress two aspects of the overall argument in this paper. The first relates to the debate on the use of liberalized markets versus central planning in the provision of energy. Specifically, this paper has outlined the implications for developing countries of the argument that an electricity system based entirely on short-run marginal costs is unlikely to deliver the required investment in renewables and backup generation. If developing countries therefore continue to adopt the standard model and progress towards fully liberalized markets in their current form (as pioneered by developed countries), absent any binding decarbonisation targets or carbon price, the end result is likely to be a market structure comprising of intermittent renewable energy with cheap coal-fired plants as backup generation. This would constitute a massive policy contradiction in a future where renewables are meant to play a significant role in climate change mitigation. However, taking this line of argument further, under liberalized markets in their current structure, backup generators in coal may not even earn back their fixed costs, which constitutes a disincentive for them to build backup generation in the present. The problem then reduces to one of investment - which is essentially the same problem currently being debated in developed countries, but which holds greater consequences in developing countries, where the concern is one of 'turning the lights on' rather than purely 'keeping the lights on'.

\footnotetext{
${ }^{68}$ Specifically, GATT 1994, Arts I. III.1, III.4, and III.5; Subsidies and Countervailing Measures, Arts 1.1, 3.1(b) and 3.2; and TRIMs, Arts. 2.1 and 2.2.

${ }^{69}$ For a summary of the issues, see Zhao (2014).
}

May 2014: Divergent Paths to a Common Goal? An Overview of Challenges to Electricity Sector Reform in 18 Developing versus Developed Countries 

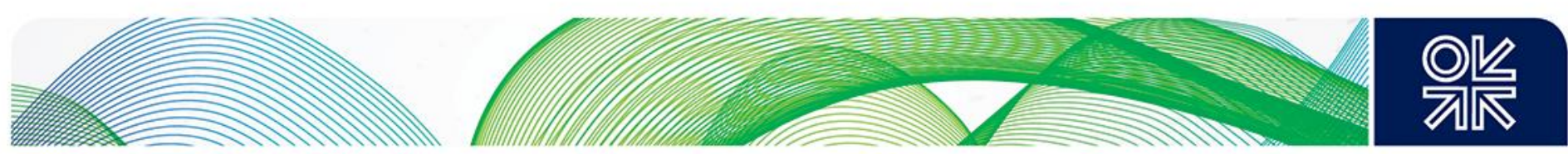

This takes us into the second aspect, which is broader, and is related to the role of coal in electricity. As discussed, coal is likely to continue to form the major proportion of electricity generation in developing countries over the next two decades. Admittedly, this is true mainly for India and China however, these two countries account for a large proportion of the developing world and will also account for the largest shares of future coal consumption (as per forecasts by the IEA), with India eventually overtaking China. The debate over electricity reforms via liberalised markets or vertical integration has thus arguably failed to account for the role of coal, particularly as it relates to costreflective pricing. The fact is that coal presents an exceptionally difficult trade-off in the case of developing countries - on the one hand, it represents a benefit, as a cheap and reliable domestic resource that is used to alleviate energy poverty and facilitate economic development. On the other hand, it is a liability, given the enormous implications of using coal on climate change and the environment. Going forward, there is therefore a need for the debate over electricity reforms and the design of electricity systems in developing countries to broaden and engage with wider aspects of development economics. One way in which the trade-off might be resolved is for developing countries to proceed with implementing the standard model (or any variations that may emerge from the current debate) and adopt cost-reflective pricing, while dealing with the distributional and poverty alleviation aspects in some other way, for instance, through targeted poverty reduction instruments rather than via the electricity system per se. This is in fact a standard economic argument, but perhaps not a very helpful one given the difficulties of implementation. Alternatively, the trade-off may be eased or resolved through technological advancements, particularly in solar energy. If these advancements allowed developing countries to adopt small scale distributed and decentralized systems, it would constitute a significant advantage, particularly if it made solar competitive with coal.

Although it may appear that the policy choices available represent one of two extremes: a continued move towards liberalized markets on a larger scale, or a return to a single buyer or central planning model, the debate is arguably not as 'black and white'. Rather, it represents a need to recognize the underlying nuances that have typically characterized electricity sector reforms in developing countries. 

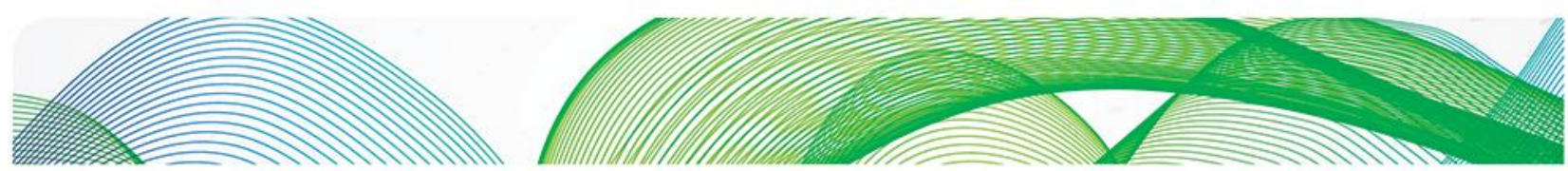

\section{References}

Andrews-Speed, P. (2013). 'Reform Postponed: The Evolution of China's Electricity Markets', in Sioshansi, F.P (ed) Evolution of Global Electricity Markets: New paradigms, new challenges, new approaches, Academic Press, Elsevier.

Bacon, R. (1999). 'A Scorecard for Energy Reform in Developing Countries', Viewpoint, note no.175, World Bank, Washington, DC.

Besant-Jones, J.E. (2006). 'Reforming Power Markets in Developing Countries: What Have We Learned?' Paper no. 19, Energy and Mining Sector Board Discussion paper, The World Bank Group.

Bower, J; Fuentes, R. (2014) 'In Search of the Mexican Way: how to kick start competition, achieve lower tariffs, and remove subsidies with the electricity reform?' Oxford Energy Comment, Oxford Institute for Energy Studies, May.

Buchan, D. (2013). 'Limiting state intervention in Europe's electricity markets', Oxford Energy Comment, Oxford Institute for Energy Studies, November.

Buchan, D. and Keay, M. (2014). 'The EU's new energy and climate goals for 2030: under-ambitious and over-bearing?' Oxford Energy Comment, Oxford Institute for Energy Studies, January.

Bye, T. and Hope. E. (2005). 'Deregulation of electricity markets - The Norwegian Experience', Discussion Paper No 433, Research Department, Statistics Norway.

Census (2011). Census of India, Government of India.

CERC (2013). Report on Short Term Power Market in India, 2012-13, Economics Division, Central Electricity Regulatory Commission, New Delhi, July.

CSE (2013). 'Scaling up Renewable Energy Mini-grids for Rural Electrification', Centre for Science and Environment Workshop, Raipur, Chhattisgarh, 12-14 August.

Drajem, M. (2013). 'Coal at Risk as Global Lenders Drop Financing on Climate', Bloomberg News Online, 6 August 2013. Available at www.bloomberg.com/news/2013-08-05/coal-at-risk-as-globallenders-drop-financing-on-climate.html.

Dubash, N.K. (2011). 'From Norm Taker to Norm Maker? Indian Energy Governance in Global Context', Global Policy, Volume 2, Issue Supplement s1, 66-79, September.

Dubash, N.K. and Singh, D. (2005). 'Of Rocks and Hard Places: A Critical Overview of Recent Global Experience with Electricity Restructuring', Economic and Political Weekly. 10-16 December.

Gol (2011). Annual Report 2011-12 on the Working of State Power Utilities and Electricity Departments, Planning Commission, Government of India, October.

Gol (2013). Smart Grid Vision and Roadmap for India, Ministry of Power, Government of India. 

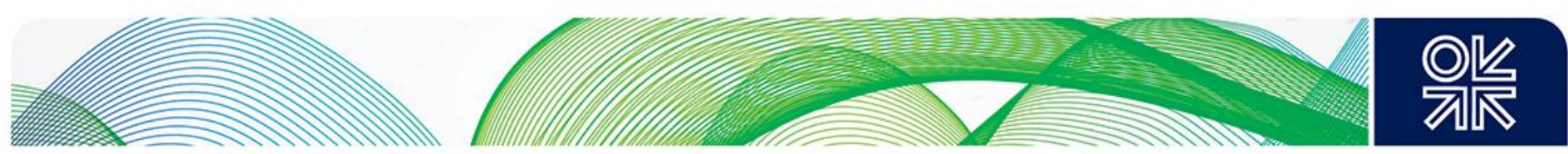

Gratwick, K.N. and Eberhard, A. (2008). 'Demise of the standard model for power sector reform and the emergence of hybrid power markets', Energy Policy, 36 (10), 3948-60.

Green, R. (2010). 'The Economics of Smart Grids', Presentation at UK-China Strategic Workshop on Smart Grids, Oxford, August.

Helm, D. (2010). 'Credibility, Commitment, and Regulation: Ex Ante Price Caps and Ex Post Interventions', in Hogan, W. and Sturzenegger, F. (eds) The Natural Resources Trap Private Investment without Public Commitment, MIT press.

IEA (2008). $\mathrm{CO}_{2}$ Emissions from Fuel Combustion, International Energy Agency, Paris.

IEA (2013). World Energy Outlook, International Energy Agency, Paris.

IPCC (2007). Climate Change 2007, Contribution of Working Group II to the Fourth Assessment Report of the Intergovernmental Panel on Climate Change, M.L. Parry, O.F. Canziani, J.P. Palutikof, P.J. van der Linden and C.E. Hanson (eds) Cambridge University Press, Cambridge, United Kingdom and New York, NY, USA.

Jamasb, T.; Mota, R.; Newbery, D.; Pollitt, M. (2004). 'Electricity Sector Reform in Developing Countries: A Survey of Empirical Evidence on Determinants and Performance', Cambridge Working Papers in Economics 0439, Faculty of Economics, University of Cambridge.

Joseph, K.L. (2010). 'The politics of power: Electricity reform in India', Energy Policy, 38(1), 503-11.

Joskow, P. (2008) 'Lessons Learned from Electricity Market Liberalization', The Energy Journal, Volume 29, Special Issue No. 2, 9-42.

Kahn, A. E. (1979). 'Applications of Economics to an Imperfect World', American Economic Review, 69(2): 1-13.

Keay, M. (2009). 'Electricity Market Liberalisation in the UK: the End is Nigh', OIES presentation, to the Electricity Policy Research Group in Cambridge on 26 January, published 1 February.

Keay, M. (2010). 'Can the Market Deliver Security and Environmental Protection in Electricity Generation?',in Rutledge, I.; Wright, P. (eds.), UK Energy Policy and the End of Market Fundamentalism, Oxford: OIES/OUP.

Keay, M. (2013a). 'Renewable energy targets: the importance of system and resource costs', Oxford Energy Comment, Oxford Institute for Energy Studies, February.

Keay, M. (2013b). 'UK Electricity Market Reform and the EU', Oxford Energy Comment, Oxford Institute for Energy Studies, April.

Keay, M., Rhys, J., and Robinson, D. (2013a). 'Electricity Market Reform in Britain: Central Planning Versus Free Markets', in Sioshansi, F.P (ed) Evolution of Global Electricity Markets: New paradigms, new challenges, new approaches, Academic Press, Elsevier.

Keay, M., Rhys, J., and Robinson, D. (2013b). 'Decarbonization of the electricity industry - is there still a place for markets?', OIES Working Paper EL9, Oxford Institute for Energy Studies, November.

Littlechild, S. (2000). 'Privatization, Competition and Regulation in the British Electricity Industry, with Implications for Developing Countries', Report 226/00 Energy Sector Management Assistance Programme (ESMAP)/World Bank, Washington, February.

May 2014: Divergent Paths to a Common Goal? An Overview of Challenges to Electricity Sector Reform in 21 Developing versus Developed Countries 

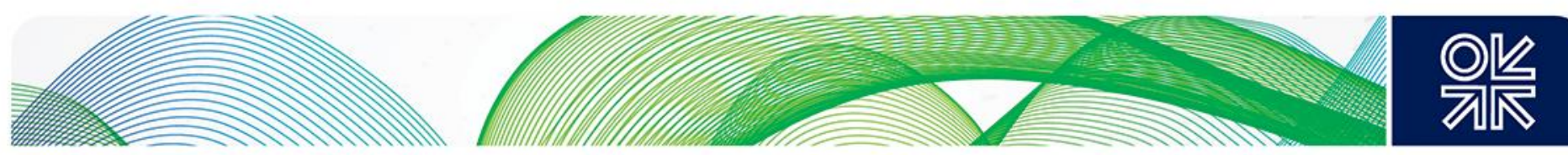

Magnus, E. (1997). 'Competition without privatisation - Norway's reforms in the power sector', Energy for Sustainable Development, 3(6), 55-61.

Nepal, R. and Jamasb, T. (2011). 'Reforming the Power Sector in Transition: Do Institutions Matter?', Cambridge Working Papers in Economics (CWPE) 1125 \& Electricity Policy Research Group Working Paper (EPRG) 1109, Electricity Policy Research Group, Faculty of Economics, University of Cambridge, February.

Newbery, D. (2000). Privatization, Restructuring and Regulation of Network Utilities, Cambridge, M.A.: MIT Press.

Newbery, D.M. (2013). 'Evolution of the British Electricity Market and the Role of Policy for the LowCarbon Future', in Sioshansi, F.P (ed) Evolution of Global Electricity Markets: New paradigms, new challenges, new approaches, Academic Press, Elsevier.

Newbery, D.M. and Pollitt, M.G. (1997). 'The Restructuring and Privatization of the U.K. Electricity Supply-Was it Worth it?' Public Policy for the Private Sector, Note No. 124, The World Bank, September.

Percebois, J. (2013). 'The French Paradox: Competition, Nuclear Rent, and Price Regulation', in Sioshansi, F.P (ed.) Evolution of Global Electricity Markets: New paradigms, new challenges, new approaches, Academic Press, Elsevier.

Pollitt, M. G. (2004). 'Electricity Reform in Chile: Lessons for Developing Countries'; CMI Working Paper 51 \& Cambridge Working Papers in Economics (CWPE) 0448, Electricity Policy Research Group, Faculty of Economics, University of Cambridge.

Raineri, R., Dyner, I., Goni, J., Castro, N., Olaya, Y. and Franco, C. (2013). 'Latin American Energy Integration: An Outstanding Dilemma' in Sioshansi, F.P (ed.) Evolution of Global Electricity Markets: New paradigms, new challenges, new approaches, Academic Press, Elsevier.

Rhys, J. (2013). 'Current German Energy Policy - the "Energiewende": A UK and climate change perspective', Oxford Energy Comment, Oxford Institute for Energy Studies, April.

Riesz, J., Gilmore, J., and Hindsberger, M. (2013). 'Market Design for the Integration of Variable Generation' in Sioshansi, F.P (ed.) Evolution of Global Electricity Markets: New paradigms, new challenges, new approaches, Academic Press, Elsevier.

Robinson, D. (2013). 'Living with intermittent renewable power: challenges for Spain and the EU', Oxford Energy Comment, Oxford Institute for Energy Studies, June.

Rosa, P., da Silva, N.F., Pereira, M.G., and Losekann, L.D. (2013). 'The Evolution of Electricity Market in Brazil' in Sioshansi, F.P (ed) Evolution of Global Electricity Markets: New paradigms, new challenges, new approaches, Academic Press, Elsevier.

Rutledge, I. (2010). 'UK Energy Policy and Market Fundamentalism: a Historical Overview', in Rutledge, I. and Wright, P. (eds.), UK Energy Policy and the End of Market Fundamentalism, Oxford: OIES/OUP.

Rutledge, I. and Wright, P. (eds.) (2010). UK Energy Policy and the End of Market Fundamentalism, Oxford: OIES/OUP. 

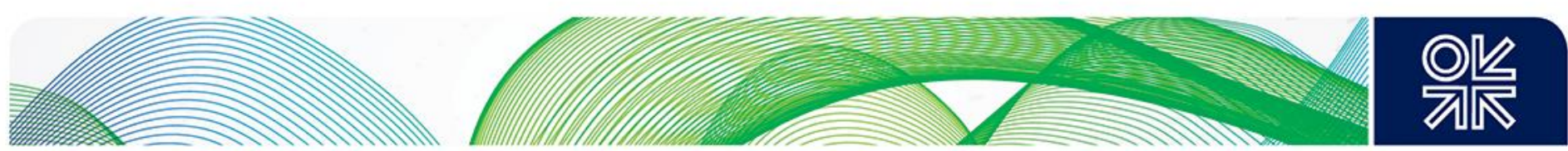

Sen, A and Jamasb, T. (2013). 'Not Seeing the Wood for the Trees? Electricity Market Reform in India' in Sioshansi, F.P (ed.) Evolution of Global Electricity Markets: New paradigms, new challenges, new approaches, Academic Press, Elsevier.

Singh, A. (2010). 'Towards a competitive market for electricity and consumer choice in the Indian power sector', Energy Policy, 38(8); 4196-208.

Tongia, R. (2007). 'The Political Economy of Indian Power Sector Reforms', in Victor, D. and Heller, T.C. (eds.), The Political Economy of Power Sector Reform: The Experiences of Five Major Developing Countries, Cambridge: CUP.

UKERC (2010). 'Electricity Market Design for a Low Carbon Future', UK Energy Research Centre Working Paper UKERC/WP/ESM/2005/004, October.

Victor, D. and Heller, T.C. (eds.) (2007). The Political Economy of Power Sector Reform: The Experiences of Five Major Developing Countries, Cambridge: CUP.

Williams, J.H. and Ghanadan, R. (2006). 'Electricity reform in developing and transition countries: a reappraisal', Energy, 31, 815-44.

Wright, P. (2006). Gas Prices in the UK: Markets and Insecurity of Supply, Oxford: OIES/OUP.

Yang, A and Cui, Y. (2012). 'Global Coal Risk Assessment: Data Analysis and Market Research', WRI Working Paper. World Resources Institute, Washington DC.

Zhang, Y., Kirkpatrick, C., and Parker, D. (2008). 'Electricity Sector Reform in Developing Countries: An Econometric Assessment of the Effects of Privatisation, Competition, and Regulation', CRC Working Paper 31/2002, Institute for Development Policy and Management, University of Manchester.

Zhao, R. (2014) 'EU- China solar dispute reveals flaws in global trade system', Oxford Energy Forum, Issue 95, Oxford Institute for Energy Studies, February. 
Appendix A: Estimated Levelized Cost of New Generation Resources, 2018 (2011US\$/Megawatt Hour)

\begin{tabular}{|c|c|c|c|c|c|}
\hline Plant Type & $\begin{array}{c}\text { Levelized } \\
\text { Capital Cost }\end{array}$ & Fixed O\&M & Variable O\&M & $\begin{array}{c}\text { Transmission } \\
\text { Investment }\end{array}$ & Total System \\
\hline \multicolumn{6}{|l|}{ Dispatchable } \\
\hline \multicolumn{6}{|l|}{ Coal } \\
\hline $\begin{array}{l}\text { Conventional } \\
\text { Coal }\end{array}$ & 65.7 & 4.1 & 29.2 & 1.2 & 100.1 \\
\hline $\begin{array}{l}\text { Advanced } \\
\text { Coal }\end{array}$ & 84.4 & 6.8 & 30.7 & 1.2 & 100.1 \\
\hline $\begin{array}{l}\text { Advanced } \\
\text { Coal CCS }\end{array}$ & 88.4 & 8.8 & 37.2 & 1.2 & 135.5 \\
\hline \multicolumn{6}{|l|}{ Natural Gas } \\
\hline $\begin{array}{l}\text { Conventional } \\
\text { Combined } \\
\text { Cycle (CC) }\end{array}$ & 15.8 & 1.7 & 48.4 & 1.2 & 67.1 \\
\hline Advanced CC & 17.4 & 2.0 & 45.0 & 1.2 & 65.6 \\
\hline $\begin{array}{l}\text { Advanced CC } \\
\text { with CCS }\end{array}$ & 34.0 & 4.1 & 54.1 & 1.2 & 93.4 \\
\hline $\begin{array}{l}\text { Conventional } \\
\text { Combustion } \\
\text { Turbine (CT) }\end{array}$ & 44.2 & 2.7 & 80.0 & 3.4 & 130.3 \\
\hline Advanced CT & 30.4 & 2.6 & 68.2 & 3.4 & 104.6 \\
\hline $\begin{array}{l}\text { Advanced } \\
\text { Nuclear }\end{array}$ & 83.4 & 11.6 & 12.3 & 1.1 & 108.4 \\
\hline Geothermal & 76.2 & 12.0 & 0.0 & 1.4 & 89.6 \\
\hline Biomass & 53.2 & 14.3 & 42.3 & 1.2 & 111.0 \\
\hline \multicolumn{6}{|c|}{ Non-Dispatchable } \\
\hline Wind & 70.3 & 13.1 & 0.0 & 3.2 & 86.6 \\
\hline Wind Offshore & 193.4 & 22.4 & 0.0 & 5.7 & 221.5 \\
\hline Solar PV & 130.4 & 9.9 & 0.0 & 4.0 & 144.3 \\
\hline Solar Thermal & 214.2 & 41.4 & 0.0 & 5.9 & 261.5 \\
\hline Hydro & 78.1 & 4.1 & 6.1 & 2.0 & 90.3 \\
\hline
\end{tabular}

Source: EIA Annual Energy Outlook 2014. Available at

http://www.eia.gov/forecasts/aeo/electricity_generation.cfm 